\title{
34. CLAY MINERALS: PALEOGEOGRAPHIC AND DIAGENETIC ASPECTS
}

\author{
Viktor Kurnosov, Nicholai Tseitlin, and Gennadi Narnov, Far East Geological Institute, \\ Far East Science Center of the Academy of Sciences of the USSR, Vladivostok
}

\section{INTRODUCTION}

Clay minerals are widespread in the sediments drilled during Leg 56. We compared composition, distribution, and origin of clay minerals in sediments from the accretionary wedge (Site 434) with those of clay minerals from the sites at the oceanic plate (Site 436) and on the landward slope of the Japan Trench (Site 435) in order to determine the mode of sediment deformation and accumulation in the Japan Trench and in its landward wall. We also tried to determine sediment source areas, means of clay mineral migration, and physico-geographical conditions of sedimentation, including paleocurrents. In addition we studied the diagenetic transformation of clay sediments in the Japan Trench and at the margin of oceanic plate, the influence of clay minerals on the chemical makeup of sediments, and their elemental distribution.

\section{METHODS}

We examined fractions less than $1 \mu \mathrm{m}$ from 1 to 10 $\mu \mathrm{m}$, and sometimes greater than $10 \mu \mathrm{m}$. These fractions were precipitated from suspension (Vikulova, 1957) and analyzed by X-ray diffraction, electron diffraction, microdiffraction, electron microscopy, and infrared methods. We also made chemical and spectral analyses.

\section{X-ray Diffraction}

We obtained X-ray diffraction patterns of oriented specimens using a DRON-1,5 X-ray diffractometer with $\mathrm{CuK}_{\alpha}$ emission and a Ni-filter. Slit openings of $0.5,1,1$, and $0.5 \mathrm{~mm}$ were used.

Each sample was dried in the air, treated with ethylene glycol, and heated at 500 to $550^{\circ} \mathrm{C}$ for 1 to 2 hours. Clay fractions were treated with 10 per cent $\mathrm{HCl}$ at 90 to $100^{\circ} \mathrm{C}$ for 1 hour for identification of kaolinite and dioctahedral and trioctahedral minerals. Expanding vermiculite was determined by Mg-ethylene glycol tests. Some samples were K-saturated to test the nature of expanding minerals after Weaver's method (Weaver, 1958). The ratio of $17-\AA$ reflection shoulders (i.e., the Z-coefficient) was calculated.

\section{Electron Diffraction Analysis and Electron Microscopy}

We obtained electron diffraction patterns using an electronograph EG-100M with accelerating voltage 100 kv. These patterns were used for determining illite polytypes, the degree of structural ordering of montmorillonite, and the $b$-parameter (accuracy $\pm 0.01 \AA$ ). Electron microdiffraction made it possible to recognize acicular crystals and amorphous phases.
The morphology of clay minerals and its relation to another sedimentary phases were analyzed using a UEMV-100K electron microscope and a ISM-U3 scanning electron microscope.

\section{Infrared Spectroscopy}

The infrared absorption spectra were obtained using a UR-20 infrared spectrometer; a tablet mixture of the specimen and $\mathrm{KBr}$ in a ratio of 1:300 was used. The infrared spectra revealed minor quantities of kaolinite, carbonate, quartz, feldspar, and other minerals as well as the structural peculiarities of expanding minerals.

\section{Quantitative Analysis}

To measure the relative proportions of clay minerals in the fractions we adopted Biscaye's method (Biscaye, 1964): $\mathrm{M}(17 \AA) / \mathrm{I}(10 \AA) / \mathrm{Ch}+\mathrm{K}(7 \AA)=1 / 4 / 2$. Infrared spectra showed the kaolinite concentration (Chester and Elderfield, 1973).

\section{RESULTS}

Polymineral clay suites composed as a rule of $17 \AA$ expanding mineral: illite, chlorite, kaolinite, and mixedlayer chlorite-montmorillonite are widespread in sediments drilled at Leg 56 sites. Palygorskite-sepiolite minerals, quartz, feldspar, zeolite, carbonate, amorphous phase, and amphibole also occur.

$17 \AA$ minerals are represented by the montmorillonite group and mixed-layer illite-montmorillonite. Montmorillonitic minerals occur only in pelagic clays in the lower part of Hole 436. They are characterized by a strong first-order basal reflection at 13.4 to $14.0 \AA$, which shifts to $16.7 \AA$ after saturation with ethylene glycol and by weak reflections appearing at about $8.5 \AA$ (002), $5.6 \AA(003)$, and $3.33 \AA$ (005). After heating at $550^{\circ} \mathrm{C}$ the reflection 001 is at $10 \AA$ (Figure 1). Montmorillonite and $\mathrm{Fe}$-montmorillonite represent the montmorillonite group. The $b$-parameter of montmorillonite is $9.01 \AA$. Montmorillonite in sediments from Site 436 is almost insoluble in 10 per cent $\mathrm{HCl}$. Figure 2 presents its infrared spectrum. Fe-montmorillonite from Sample $436-41-1,34-36 \mathrm{~cm}$ is soluble in hot 10 per cent $\mathrm{HCl}$. Its infrared spectrum is similar to that of montronite (Figure 2).

Electron diffraction patterns of montmorillonite and Fe-montmorillonite show small, transparent for electrons, cloud-shaped and large opaque particles (Plate $2)$. The scanning electron microscope shows foliated morphology of clay particles (Plates 3,4$)$. Plate 5 shows electron diffraction patterns of montmorillonite and Femontmorillonite. 


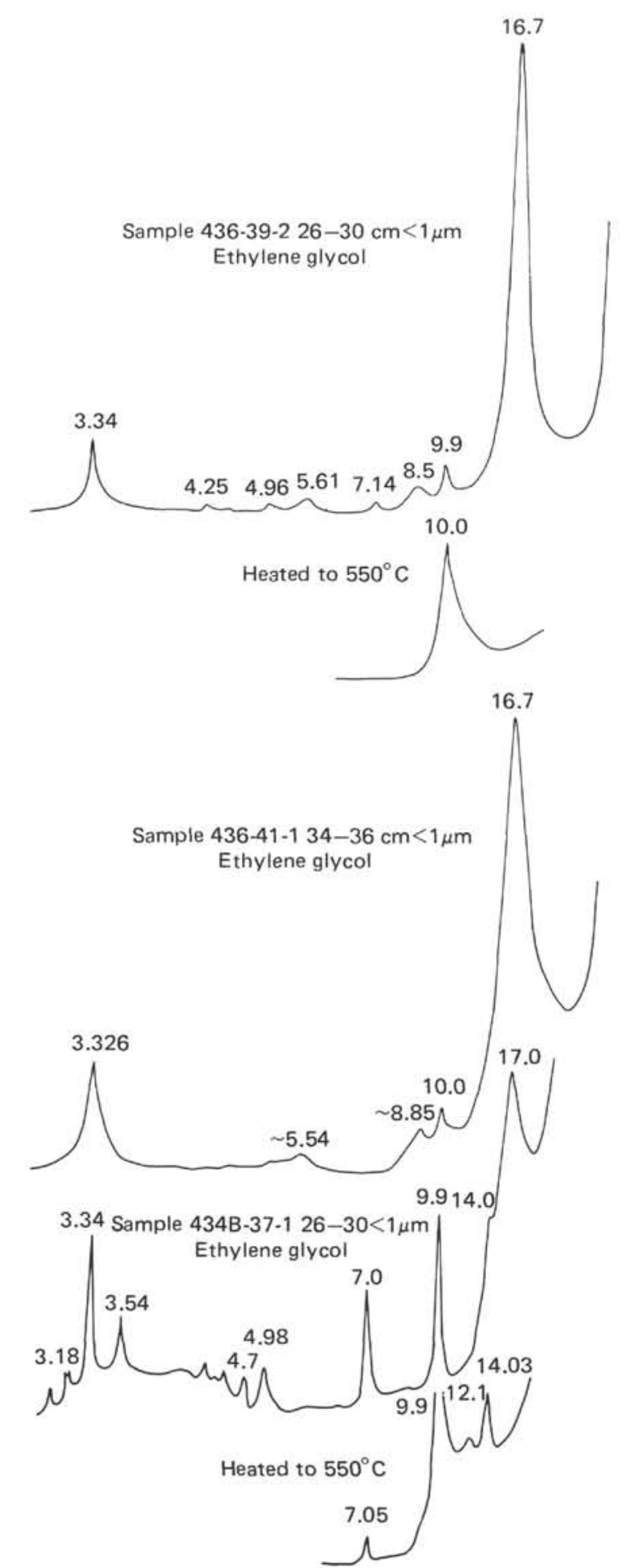

Figure 1. X-ray diffraction patterns of the less than $1 \mu \mathrm{m}$ fraction from Leg 56 (spacings in $A$ ).

Expanding minerals, diffraction patterns of which display asymmetrical, broadened $17 \AA$ reflection, are most typical of sediments drilled on Leg 56. The $\mathrm{Z}$-coefficient is in the range of 0.4 to 0.5 . Basal reflections of longer-range order are absent in diffraction patterns. Heating specimens at 500 to $550^{\circ} \mathrm{C}$ for 1 hour results in reflection 001 shift to the position $10 \AA$

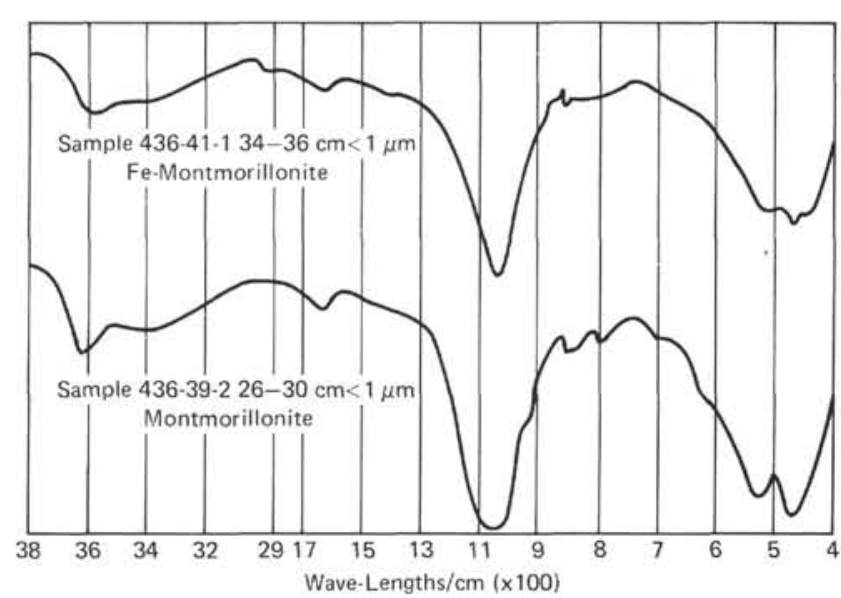

Figure 2. Infrared absorption spectra of Fe-montmorillonite and montmorillonite from Site 436.

(Figure 1). Such diffraction patterns are characteristic of entirely disordered mixed-layer illite-montmorillonitic minerals (Dritz and Sakharov, 1976). The electron diffraction patterns and infrared spectra of these minerals show illite reflections, whereas montmorillonite reflections are absent or negligible (Plate 5, Figure 3 ). The expanding phase of mixed-layer minerals is represented either by montmorillonite or by coexisting montmorillonite and Fe-montmorillonite. Various expanding layers are recognizable by the dissolution of mixed-layer mineral in 10 per cent $\mathrm{HCl}$. The morphology of mixed-layer mineral is similar to that of montmorillonite (Plate 1). Scanning electron diffraction patterns show the structure of sediments containing mixed-layer minerals (Plate 3 ).

Illite is common in samples recovered during Leg 56. It is easily recognized by a series of reflections based on $10 \AA$ periodicity (Figure 1). The intensity ratio of the first three basal reflections and the $b$-parameter $(b=$ $9.02 \AA$ ) identifies the illite as a dioctehedral $\mathrm{Fe}-\mathrm{Al}$ variety. Electron diffraction analysis further identified two polytype modifications of illite, $2 \mathrm{M}_{1}$ and $1 \mathrm{M}$ (Plate 5, Figure 3).

Chlorite is identified by a series of basal reflections based on $14.1 \AA$ periodicity. Even-to-odd reflection ratios and the $b$ parameter $(b=9.25 \AA)$ identify chlorites in sediments recovered during Leg 56 as being of the $\mathrm{Fe}-\mathrm{Mg}$ trioctahedral variety. When treated by hot $\mathrm{HCl}$, illite always dissolves. That saturation of the specimen with ethylene glycol does not result in a shift of its basal reflections indicates the stability of the chlorite structure. Sometimes the first basal reflection moves to the range of 0.5 to $0.8 \AA$, revealing the presence of negligible quantities of interlayed smectite. Heating at 500 to $550^{\circ} \mathrm{C}$ identified two chlorite varieties: stable chlorite characterized by 001 reflection at 14 to $14.03 \AA$ and chlorite with a watered brucitic layer revealed by an 001 reflection at 13.8 to $13.9 \AA$.

Kaolinite is scarce. It is identified by electron diffraction and by the absorption band $3700 \mathrm{~cm}^{-1}$ of the infrared spectra. Because it is unaffected by heating with 10 


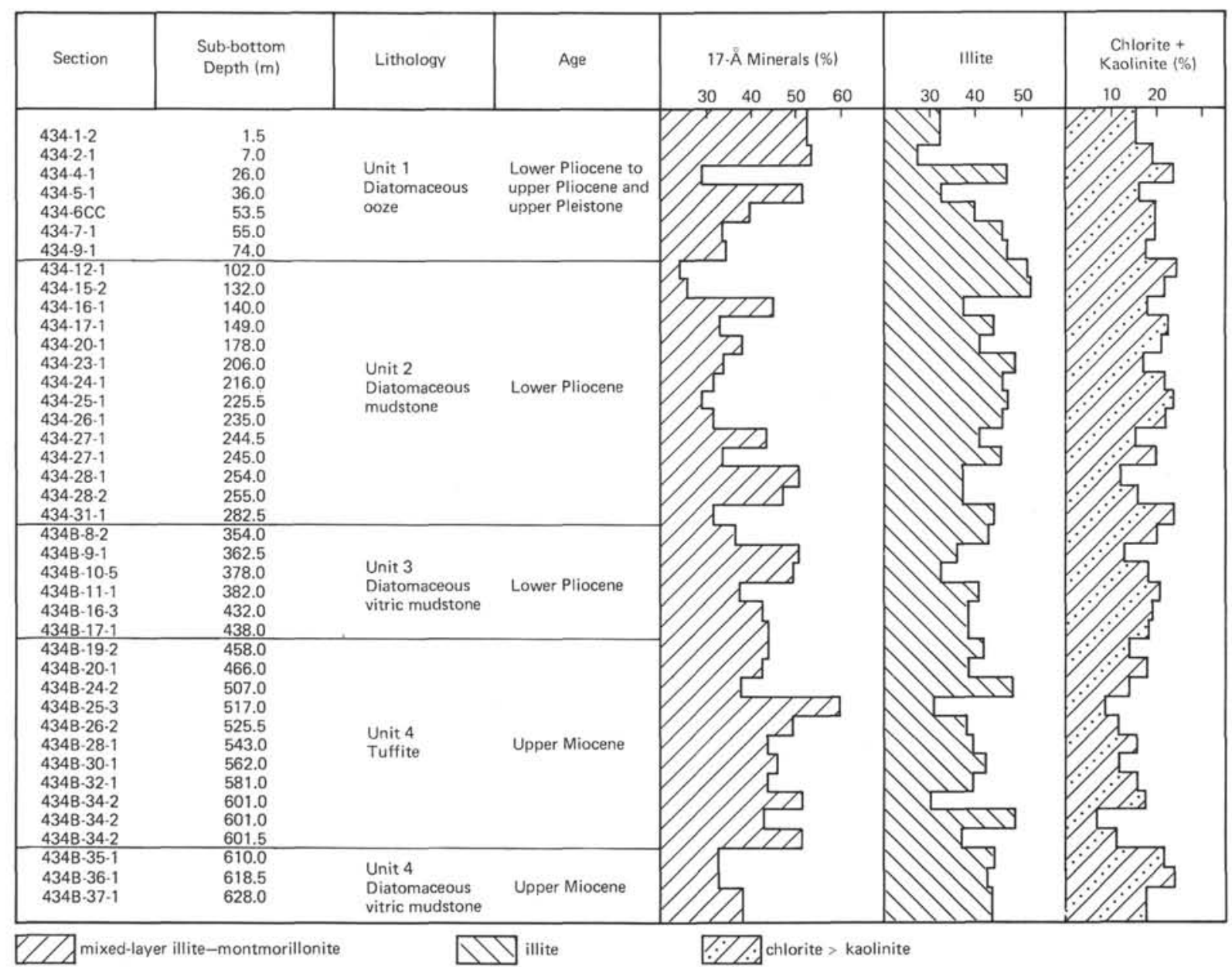

Figure 3. Variations in clay minerals composition of the less than $1 \mu \mathrm{m}$ fraction from Site 434.

per cent $\mathrm{HCl}$, it is easily recognized in the X-ray diffraction patterns of samples so treated.

Mixed-layer chlorite - montmorillonite mineral occurs in small amounts. It is revealed through heating at $550^{\circ} \mathrm{C}$ by small reflection at 11.6 to $12.8 \AA$. The peak is often broadened. Mixed-layer mineral is also identified by the asymmetry of the $10 \AA$ peak.

Palygorskite - sepiolitic minerals are observed in electron diffraction patterns as a ring at 10.4 to $12 \AA$ of individual samples (Plate 2). They are undetectable on $\mathrm{X}$-ray diffraction patterns and infra-red spectra because they occur in minor quantities. Electron diffraction analysis confirmed that acicular crystals from Sample 436-41-1, 10-12 cm, were palygorskites.

Quartz and feldspar are recognized in X-ray diffraction patterns by 4.25 and 3.34 reflections (quartz) and by $3.18 \AA$ reflection (feldspar) as well as in electron diffraction patterns and infrared spectra.

Carbonates are identified in trace quantities on infrared spectra by the absorption band at 1400 to 1500 $\mathrm{cm}^{-1}$.

Zeolites were identified by X-ray diffraction analysis in a few samples. They are seen clearly only in scanning electron microscope photographs (Plates 3,4).

\section{DISTRIBUTION OF CLAY AND COEXISTING MINERALS}

\section{Site 434}

Clay mineral composition in fractions of less than 1 $\mu \mathrm{m}$ is rather monotonous (Table 1). Mixed-layer illitemontmorillonite and illite prevail. The proportion of mixed-layer and other clay minerals is uniform throughout the 600-meter section. Mixed-layer mineral averages 35 to 45 per cent of the total number of clay minerals and ranges from 25 to 60 per cent. Expanding beds in the mixed-layer mineral are of two types: Fe-montmorillonitic and montmorillonitic (Table 2). The proportions are invariable throughout the site. In all samples the 17 - $\AA$ mineral reacts with 10 per cent $\mathrm{HCl}$ as well as with ethylene glycol after saturation with $\mathrm{Mg}$ (Table 2).

Throughout the site, mixed-layer mineral in upper Miocene-upper Pleistocene sediments from the Sea of Japan varies neither in quantity nor in composition (Figure 3).

Illite distribution patterns at Site 434 are similar to those of mixed-layer illite-montmorillonitic -35 to 45 per cent. All samples are of the dioctahedral $\mathrm{Fe}-\mathrm{Al}$ variety, with two polytypes: $2 \mathrm{M}_{1}$ and $1 \mathrm{M}$. The $2 \mathrm{M}_{1}$ polytype 
TABLE 1

Clay Mineral Composition and Related Minerals in DSDP Holes 434 and 434B

\begin{tabular}{|c|c|c|c|c|c|c|c|c|c|c|c|c|c|c|c|c|c|c|c|c|c|}
\hline \multirow{2}{*}{$\begin{array}{c}\begin{array}{c}\text { Sample } \\
\text { (Interval in } \mathrm{cm} \text { ) }\end{array}\end{array}$} & \multirow{2}{*}{$\begin{array}{l}\text { Sub-bottom } \\
\text { Depth } \\
\text { (m) }\end{array}$} & \multirow[b]{2}{*}{ Lithology } & \multirow[b]{2}{*}{ Age } & \multicolumn{2}{|c|}{$\begin{array}{c}\text { Mixed-Layer } \\
\text { Illite- } \\
\text { Montmorillonite } \\
(\%)\end{array}$} & \multicolumn{2}{|c|}{$\begin{array}{l}\text { Illite } \\
(\%)\end{array}$} & \multicolumn{2}{|c|}{$\begin{array}{c}\text { Chlorite + } \\
\text { Kaolinite } \\
(\%)\end{array}$} & \multicolumn{2}{|c|}{$\begin{array}{c}\text { Mixed-Layer } \\
\text { Chlorite- } \\
\text { Montmorillonite } \\
(\%)\end{array}$} & \multicolumn{2}{|c|}{$\mathrm{z}$} & \multicolumn{2}{|c|}{$\begin{array}{c}\text { Quartz } \\
(\%)\end{array}$} & \multicolumn{2}{|c|}{$\begin{array}{l}\text { Feldspar } \\
(\%)\end{array}$} & \multicolumn{2}{|c|}{$\begin{array}{c}\text { Carbonate } \\
(\%)\end{array}$} & \multicolumn{2}{|c|}{$\begin{array}{c}\text { Amorphous } \\
(\%)\end{array}$} \\
\hline & & & & $<1 \mu \mathrm{m}$ & $1-10 \mu \mathrm{m}$ & $<1 \mu \mathrm{m}$ & $1-10 \mu \mathrm{m}$ & $<1 \mu \mathrm{m}$ & $1-10 \mu \mathrm{m}$ & $<1 \mu \mathrm{m}$ & $1-10 \mu \mathrm{m}$ & $<1 \mu \mathrm{m}$ & $1-10 \mu \mathrm{m}$ & $<1 \mu \mathrm{m}$ & $1-10 \mu \mathrm{m}$ & $<1 \mu \mathrm{m}$ & $1-10 \mu \mathrm{m}$ & $<1 \mu \mathrm{m}$ & $1-10 \mu \mathrm{m}$ & $<1 \mu \mathrm{m}$ & $1-10 \mu \mathrm{m}$ \\
\hline $434-1-2(30-35)$ & 1.5 & Unit 1 & Lower & 53 & & 32 & & 15 & & tr & no & 0.6 & & tr & & tr & & tr & no & + & \\
\hline 434-2-1 (93-97) & 7.0 & Diatoma- & Pliocene & 54 & & 27 & & 19 & & no & & 0.6 & & tr & & tr & & & & + & \\
\hline 434-4-1 (90-94) & 26.0 & ceous ooze & to upper & 29 & 25 & 47 & 43 & 24 & 32 & no & tr & 0.6 & 0.6 & tr & ++ & tr & + & & & + & t+ \\
\hline 434-5-1 (115-119) & 36.0 & & Pliocene & 52 & & 32 & & 16 & & no & & 0.6 & & tr & & tr & & & & + & \\
\hline $434-6, \mathrm{CC}(22-26)$ & 53.5 & & and upper & 40 & & 40 & & 20 & & $\mathrm{tr}$ & & 0.4 & & tr & & tr & & & & + & \\
\hline 434-7-1 (120-124) & 55.0 & & Pleis- & 34 & 42 & 46 & 36 & 20 & 22 & tr & tr & 0.4 & 0.4 & tr & & to & & tr & & + & \\
\hline $434-9-1(130-134)$ & 74.0 & & tocene & 35 & & 47 & & 18 & & tr & & 0.5 & & tr & & tr & & & & + & \\
\hline $434-12-1(85-89)$ & 102.0 & Unit 2 & Lower & 25 & 32 & 51 & 40 & 24 & 28 & tr & no & 0.3 & 0.4 & tr & ++ & tr & + & tr & no & + & H \\
\hline $434-15-2(70-73)$ & 132.0 & Diatoma- & Pliocene & 26 & & 52 & & 22 & & no & & 0.5 & & tr & & tr & & & & + & \\
\hline $434-16-1(63-67)$ & 140.0 & ceous mud- & & 45 & 40 & 37 & 35 & 18 & 25 & tr & tr & 0.6 & 0.5 & tr & ++ & tr & + & & & + & + \\
\hline $434-17-1(6-10)$ & 149.0 & stone & & 33 & & 44 & & 23 & & tr & & 0.5 & & + & & tr & & & & + & \\
\hline $434-20-1(58-62)$ & 178.0 & & & 38 & & 41 & & 21 & & tr & & 0.5 & & tr & & tr & & & & + & \\
\hline $434-23-1(40-44)$ & 206.0 & & & 34 & 25 & 49 & 54 & 17 & 21 & tr & no & 0.4 & 0.4 & tr & ++ & tr & + & & & + & ++ \\
\hline $434-24-1(91-95)$ & 216.0 & & & 32 & & 46 & & 22 & & ts & & 0.3 & & tr & & tr & & & & + & \\
\hline $434-25-1(62-66)$ & 225.5 & & & 29 & & 47 & & 24 & & tr & & 0.4 & & tr & & tr & & & & + & \\
\hline $434-26-1(52-56)$ & 235.0 & & & 32 & & 46 & & 22 & & tr & & 0.5 & & tr & & tr & & & & + & \\
\hline $434-27-1(77-81)$ & 244.5 & & & 44 & & 41 & & 15 & & tr & & 0.4 & & tr & & tr & & & & + & \\
\hline $434-27-1(103-108)$ & 245.0 & & & 34 & & 46 & & 20 & & tr & & 0.5 & & tr & & ts & & & & + & \\
\hline $434-28-1(86-90)$ & 254.0 & & & 51 & & 37 & & 12 & & tr & tr & 0.5 & & tr & & tr & & & & tr & \\
\hline $434-28-2(45-47)$ & 255.0 & & & 47 & & 37 & & 16 & & tr & a & 0.4 & & tr & & tr & & & & + & \\
\hline $434-31-1(51-55)$ & 282.5 & & & 32 & 40 & 44 & 40 & 24 & 20 & tr & tr & 0.4 & 0.4 & tr & + & tr & + & tr & & + & +t \\
\hline 434B-8-2 (33-37) & 354.0 & Unit 3 & Lower & 37 & 43 & 43 & 36 & 20 & 21 & tr & & 0.4 & 0.4 & tr & ++ & tr & + & tr & no & + & H \\
\hline 434B-9-1 (80-84) & 362.5 & Diatoma- & Pliocene & 51 & & 36 & & 13 & & tr & & 0.5 & & tr & & tr & & & & + & \\
\hline $434 \mathrm{~B}-10-5(80-84)$ & 378.0 & ceous vit- & & 50 & & 32 & & 18 & & tr & & 0.5 & & tr & & tr & & & & + & \\
\hline $434 \mathrm{~B}-11-1(100-104)$ & 382.0 & ric mud- & & 38 & & 41 & & 21 & & tr & & 0.4 & & tr & & tr & & & & + & \\
\hline $434 \mathrm{~B}-16-3(100-104)$ & 432.0 & stone & & 43 & 26 & 38 & 48 & 19 & 26 & tr & no & 0.3 & 0.5 & tr & H & tr & + & tr & & + & +t \\
\hline $434 \mathrm{~B}-17-1(100-109)$ & 438.0 & & & 44 & & 38 & & 18 & & tr & & 0.4 & & tr & & tr & & & & + & \\
\hline 434B-19-2 (80-84) & 458.0 & Unit 4 & Upper & 44 & & 42 & & 14 & & no & & 0.2 & & tr & & tr & & & & + & \\
\hline 434B-20-1 (80-84) & 466.0 & Tuffite & Miocene & 43 & & 39 & & 18 & & no & & 0.5 & & tr & & tr & & & & + & \\
\hline $434 \mathrm{~B}-24-2(100-106)$ & 507.0 & & & 38 & 46 & 48 & 43 & 14 & 11 & no & tr & 0.2 & 0.2 & tr & ++ & tr & + & tr & no & + & ++ \\
\hline 434B-25-3 (20-24) & 517.0 & & & 60 & & 31 & 43 & 9 & $\pi$ & no & . & 0.4 & 0.2 & tr & 7 & tr & 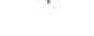 & a & & + & +7 \\
\hline $434 \mathrm{~B}-26-2(80-84)$ & 525.5 & & & 50 & & 38 & & 12 & & no & & 0.4 & & tr & & tr & & & & + & \\
\hline $434 \mathrm{~B}-28-1(70-74)$ & 543.0 & & & 44 & & 40 & & 16 & & tr & tr & 0.3 & & tr & & tr & & tr & & + & \\
\hline 434B-30-1 (65-69) & 562.0 & & & 46 & & 42 & & 12 & & no & & 0.4 & & tr & & tr & & & & + & \\
\hline 434B-32-1 (95-99) & 581.0 & & & 44 & & 40 & & 16 & & tr & & 0.4 & & tr & & tr & & & & + & \\
\hline 434B-33-1 (145) & 591.0 & & & 18 & 22 & 78 & 70 & 4 & 8 & no & no & 0.1 & 0.1 & tr & H & tr & + & & & no & \\
\hline $434 \mathrm{~B}-34-2(16)$ & 601.0 & & & 52 & & 30 & & 18 & & no & & 0.3 & & ++ & & + & & tr & & + & \\
\hline $434 \mathrm{~B}-34-2(19)$ & 601.0 & & & 44 & & 49 & & 7 & & no & & 0.3 & & tr & & $t t$ & & & & no & \\
\hline $434 \mathrm{~B}-34-2(80-84)$ & 601.5 & & & 52 & & 37 & & 11 & & tr & & 0.3 & & tr & & tr & & & & + & \\
\hline 434B-35-1 (105-109) & 610.0 & Unit 5 & Upper & 33 & & 45 & & 22 & & tr & & 0.4 & & tr & & tr & & & & + & \\
\hline $434 \mathrm{~B}-36-1(19-23)$ & 618.5 & Diatoma- & Miocene & 33 & & 43 & & 24 & & tr & & 0.3 & & tr & & tr & & & & + & \\
\hline 434B-37-1 (29-30) & 628.0 & $\begin{array}{l}\text { ceous vit- } \\
\text { ric mud- } \\
\text { stone }\end{array}$ & & 38 & & 44 & & 18 & & tr & no & 0.4 & & tr & & tr & & tr & no & + & \\
\hline
\end{tabular}

Note: $\mathrm{Z}=$ ratio of shoulders of the $17-\AA$ reflection of mixed-layer illite-montmorillonite, $++=$ abundant,$+=$ common, $t r=$ trace. 
TABLE 2

Sample Tests from DSDP Holes 434 and 434B

\begin{tabular}{|c|c|c|c|c|c|c|c|}
\hline \multirow[b]{2}{*}{ Section } & \multirow{2}{*}{$\begin{array}{l}\text { Sub-bottom } \\
\text { Depth } \\
\text { (m) }\end{array}$} & \multirow[b]{2}{*}{ Lithology } & \multirow[b]{2}{*}{ Age } & \multicolumn{2}{|c|}{$\begin{array}{c}10 \% \mathrm{HC} 1 \\
1 \text { hour at } 90-100^{\circ} \mathrm{C}\end{array}$} & \multicolumn{2}{|c|}{$\begin{array}{l}1 \mathrm{~N} \mathrm{MgC1} 2 \\
\text { ethylene glycol }\end{array}$} \\
\hline & & & & $<1 \mu \mathrm{m}$ & $1-10 \mu \mathrm{m}$ & $<1 \mu \mathrm{m}$ & $1-10 \mu \mathrm{m}$ \\
\hline $434-1-2$ & 1.5 & $\begin{array}{c}\text { Unit } 1 \\
\text { Diatomaceous }\end{array}$ & $\begin{array}{l}\text { Lower Pliocene } \\
\text { to upper } \\
\text { Pleistocene }\end{array}$ & $\mathrm{Fe}-\mathrm{m} \approx \mathrm{m}$ & $\mathrm{Fe}-\mathrm{m}>\mathrm{m}$ & no verm & no verm \\
\hline $\begin{array}{l}434-12-1 \\
434-23-1\end{array}$ & $\begin{array}{l}102.0 \\
206.0\end{array}$ & \begin{tabular}{l}
\multicolumn{1}{c}{ Unit 2} \\
Diatomaceous \\
Mudstone
\end{tabular} & Lower Pliocene & $\begin{array}{l}\mathrm{Fe}-\mathrm{m} \approx \mathrm{m} \\
\mathrm{Fe}-\mathrm{m}>\mathrm{m}\end{array}$ & $\begin{array}{l}\text { Fe-m }>m \\
\text { Fe-m }>m\end{array}$ & $\begin{array}{l}\text { no verm } \\
\text { no verm }\end{array}$ & $\begin{array}{l}\text { no verm } \\
\text { no verm }\end{array}$ \\
\hline $434 \mathrm{~B}-8-2$ & 354.0 & $\begin{array}{l}\quad \text { Unit } 3 \\
\text { Diatomaceous } \\
\text { vitric } \\
\text { mudstone }\end{array}$ & Lower Pliocene & $\mathrm{Fe}-\mathrm{m}>\mathrm{m}$ & $\mathrm{Fe}-\mathrm{m}>\mathrm{m}$ & no verm & no verm \\
\hline $\begin{array}{l}434 \mathrm{~B}-24-2 \\
434 \mathrm{~B}-33-1 \\
\end{array}$ & $\begin{array}{l}507.0 \\
591.0\end{array}$ & $\begin{array}{l}\text { Unit } 4 \\
\text { Tuffite }\end{array}$ & Upper Miocene & $\begin{array}{l}\mathrm{Fe}-\mathrm{m} \approx \mathrm{m} \\
\mathrm{Fe}-\mathrm{m}>\mathrm{m}\end{array}$ & $\begin{array}{l}\mathrm{Fe}-\mathrm{m} \approx \mathrm{m} \\
\mathrm{Fe}-\mathrm{m} \approx \mathrm{m}\end{array}$ & no verm & $\begin{array}{l}\text { no verm } \\
\text { no verm }\end{array}$ \\
\hline $434 \mathrm{~B}-37-1$ & 628.0 & $\begin{array}{l}\quad \text { Unit } 5 \\
\text { Diatomaceous } \\
\text { vitric } \\
\text { mudstone }\end{array}$ & Upper Miocene & $\mathrm{Fe}-\mathrm{m} \approx \mathrm{m}$ & Fe-m $>m$ & no verm & no verm \\
\hline
\end{tabular}

Note: $\mathrm{Fe}-\mathrm{m}=\mathrm{Fe}$-montmorillonite, $\mathrm{m}=$ montmorillonite, verm $=$ vermiculite,$\approx=$ approximately equals.

always prevails (Table 3 ); the $1 \mathrm{M}$ polytype increases with depth.

Table 1 shows coexisting chlorite and kaolinite. They are distributed evenly throughout the site and average 15 to 20 per cent, in fractions of less than $1 \mu \mathrm{m}$. The $\mathrm{X}$-ray diffraction patterns of specimens treated with 10 per cent $\mathrm{HCl}$ and the infrared spectra always show 3 to 5 per cent of kaolinite. Chlorite in all samples is of the trioctahedral $\mathrm{Fe}-\mathrm{Mg}$ variety. Chlorites containing montmorillonitic beds and hydrated brucitic layer are rare, but evenly distributed. There is mixed-layer chlorite-montmorillonite almost throughout the site. It is sometimes undetectable in Unit 1 and is virtually absent in tuffites.

Quartz, feldspar, and carbonate are found in trace amounts in all samples. Amorphous phase is abundant.

\section{TABLE 3}

Poly types of Illite in DSDP Holes 434 and 434B

\begin{tabular}{|c|c|c|c|c|c|}
\hline \multirow[b]{2}{*}{ Section } & \multirow{2}{*}{$\begin{array}{l}\text { Sub-bottom } \\
\text { Depth } \\
\text { (m) }\end{array}$} & \multirow[b]{2}{*}{ Lithology } & \multirow[b]{2}{*}{ Age } & \multicolumn{2}{|c|}{ Polytype } \\
\hline & & & & $<1 \mu \mathrm{m}$ & $1-10 \mu \mathrm{m}$ \\
\hline $\begin{array}{l}434-1-2 \\
434-7-1\end{array}$ & $\begin{array}{r}1.5 \\
55.0\end{array}$ & $\begin{array}{l}\text { Unit } 1 \\
\text { Diatomaceous } \\
\text { ooze }\end{array}$ & $\begin{array}{l}\text { Lower } \\
\text { Pliocene to } \\
\text { upper Plio- } \\
\text { cene and } \\
\text { upper } \\
\text { Pleistocene }\end{array}$ & $\begin{array}{l}2 \mathrm{M}_{1}>1 \mathrm{M} \\
2 \mathrm{M}_{1}>1 \mathrm{M}\end{array}$ & $2 \mathrm{M}_{1}>1 \mathrm{M}$ \\
\hline $\begin{array}{l}434-12-1 \\
434-23-1 \\
434-31-1 \\
\end{array}$ & $\begin{array}{l}102.0 \\
206.0 \\
282.5 \\
\end{array}$ & $\begin{array}{l}\text { Unit } 2 \\
\text { Diatomaceous } \\
\text { Mudstone }\end{array}$ & $\begin{array}{l}\text { Lower } \\
\text { Pliocene }\end{array}$ & $\begin{array}{l}2 \mathrm{M}_{1}>1 \mathrm{M} \\
2 \mathrm{M}_{1}>1 \mathrm{M} \\
2 \mathrm{M}_{1}>1 \mathrm{M}\end{array}$ & $2 \mathrm{M}_{1} \gg 1 \mathrm{M}$ \\
\hline $\begin{array}{l}434 \mathrm{~B}-8-2 \\
434 \mathrm{~B}-16-3\end{array}$ & $\begin{array}{l}354.0 \\
432.0\end{array}$ & $\begin{array}{l}\quad \text { Unit } 3 \\
\text { Diatomaceous } \\
\text { vitric mud- } \\
\text { stone }\end{array}$ & $\begin{array}{l}\text { Lower } \\
\text { Pliocene }\end{array}$ & $\begin{array}{l}2 \mathrm{M}_{1}>1 \mathrm{M} \\
2 \mathrm{M}_{1}>1 \mathrm{M}\end{array}$ & $2 \mathrm{M}_{1}>1 \mathrm{M}$ \\
\hline $\begin{array}{l}434 \mathrm{~B}-19-2 \\
434 \mathrm{~B}-24-2 \\
434 \mathrm{~B}-28-1 \\
\end{array}$ & $\begin{array}{l}458.0 \\
507.0 \\
543.0\end{array}$ & $\begin{array}{c}\text { Unit } 4 \\
\text { Tuffite }\end{array}$ & $\begin{array}{l}\text { Upper } \\
\text { Miocene }\end{array}$ & $\begin{array}{l}2 \mathrm{M}_{1}>1 \mathrm{M} \\
2 \mathrm{M}_{1}>1 \mathrm{M} \\
2 \mathrm{M}_{1}>1 \mathrm{M}\end{array}$ & $2 \mathrm{M}_{1}>1 \mathrm{M}$ \\
\hline $434 \mathrm{~B}-37-1$ & 628.0 & \begin{tabular}{l}
\multicolumn{1}{c}{ Unit 5} \\
Diatomaceous \\
vitric mud- \\
stone
\end{tabular} & $\begin{array}{l}\text { Upper } \\
\text { Miocene }\end{array}$ & $2 \mathrm{M}_{1}>1 \mathrm{M}$ & $2 \mathrm{M}_{1}>1 \mathrm{M}$ \\
\hline
\end{tabular}

Note: $>=$ much greater than.
The composition and proportion of clay minerals in fractions 1 to $10 \mu \mathrm{m}$ and less than $1 \mu \mathrm{m}$ are similar, though fractions of 1 to $10 \mu \mathrm{m}$ contain more quartz, feldspar, and amorphous phase. Carbonate and kaolinite are negligible. Mixed-layer 17 - $\AA$ mineral once again shows a Z-coefficient decrease with depth as micaceous layers increase (Table 2).

The $b$-parameter in dioctahedral minerals increases (Table 4) - that is, minerals in fractions 1 to $10 \mu \mathrm{m}$ are more enriched in iron. The ratio of $2 \mathrm{M}_{1}$ and $1 \mathrm{M}$ illitic polytypes in the 1 to $10 \mu \mathrm{m}$ fraction does not change relative to the less-than- $1 \mu \mathrm{m}$ fraction.

TABLE 4

The $b$-Parameter in DSDP Holes 434 and 434B

\begin{tabular}{|c|c|c|c|c|c|}
\hline \multirow[b]{2}{*}{ Section } & \multirow{2}{*}{$\begin{array}{l}\text { Sub-bottom } \\
\text { Depth } \\
\text { (m) }\end{array}$} & \multirow[b]{2}{*}{ Lithology } & \multirow[b]{2}{*}{ Age } & \multicolumn{2}{|c|}{$b$-Parameter $(\AA)$} \\
\hline & & & & $<1 \mu \mathrm{m}$ & $1-10 \mu \mathrm{m}$ \\
\hline $\begin{array}{l}434-1-2 \\
434-7-1\end{array}$ & $\begin{array}{r}1.5 \\
55.0\end{array}$ & $\begin{array}{l}\quad \text { Unit } 1 \\
\text { Diatomaceous } \\
\text { ooze }\end{array}$ & $\begin{array}{l}\text { Lower Plio- } \\
\text { cene to } \\
\text { upper Plio- } \\
\text { cene and } \\
\text { upper } \\
\text { Pleistocene }\end{array}$ & $\begin{array}{l}b_{1}=9.01 \\
b_{2}=9.25 \\
b_{1}=9.04 \\
b_{2}=9.25\end{array}$ & $\begin{array}{l}b_{1}=9.045 \\
b_{2}=9.26\end{array}$ \\
\hline $\begin{array}{l}434-12-1 \\
434-23-1 \\
434-31-1\end{array}$ & $\begin{array}{l}102.0 \\
206.0 \\
282.5\end{array}$ & \begin{tabular}{l}
\multicolumn{1}{c}{ Unit 2} \\
Diatomaceous \\
mudstone
\end{tabular} & $\begin{array}{l}\text { Lower } \\
\text { Pliocene }\end{array}$ & $\begin{array}{l}b_{1}=9.04 \\
b_{2}=9.25 \\
b_{1}=9.02 \\
b_{2}=9.25 \\
b_{1}=9.01 \\
b_{2}=9.25\end{array}$ & $\begin{array}{l}b_{1}=9.045 \\
b_{2}=9.26\end{array}$ \\
\hline $\begin{array}{l}\text { 434B-8-2 } \\
434 \mathrm{~B}-16-3\end{array}$ & $\begin{array}{l}354.0 \\
432.0\end{array}$ & $\begin{array}{l}\quad \text { Unit } 3 \\
\text { Diatomaceous } \\
\text { vitric mud- } \\
\text { stone }\end{array}$ & $\begin{array}{l}\text { Lower } \\
\text { Pliocene }\end{array}$ & $\begin{array}{l}b_{1}=9.04 \\
b_{2}=9.25 \\
b_{1}=9.04 \\
b_{2}=9.25\end{array}$ & $\begin{array}{l}b_{1}=9.04 \\
b_{2}=9.27\end{array}$ \\
\hline $\begin{array}{l}434 \mathrm{~B}-19-2 \\
434 \mathrm{~B}-24-2\end{array}$ & $\begin{array}{l}458.0 \\
507.0\end{array}$ & $\begin{array}{l}\text { Unit } 4 \\
\text { Tuffite }\end{array}$ & $\begin{array}{l}\text { Upper } \\
\text { Miocene }\end{array}$ & $\begin{array}{l}b_{1}=9.04 \\
b_{2}=9.25 \\
b_{1}=9.01\end{array}$ & $\begin{array}{l}b_{1}=9.04 \\
b_{1}=9.04\end{array}$ \\
\hline $434 \mathrm{~B}-28-1$ & 543.0 & & & $\begin{array}{l}b_{2}=9.25 \\
b_{1}=9.00\end{array}$ & $b_{2}=9.26$ \\
\hline $434 \mathrm{~B}-34-2$ & 601.5 & & & $\begin{array}{l}b_{1}=9.01 \\
b_{2}=9.25\end{array}$ & \\
\hline $434 \mathrm{~B}-37-1$ & 628.0 & $\begin{array}{l}\quad \text { Unit } 5 \\
\text { Diatomaceous } \\
\text { vitric mud- } \\
\text { stone }\end{array}$ & $\begin{array}{l}\text { Upper } \\
\text { Miocene }\end{array}$ & $\begin{array}{l}b_{1}=9.00 \\
b_{2}=9.25\end{array}$ & $\begin{array}{l}b_{1}=9.02 \\
b_{2}=9.24\end{array}$ \\
\hline
\end{tabular}


The X-ray diffraction patterns of the 1 to $10 \mu \mathrm{m}$ fraction show a weak reflection at $8.3 \AA$ (amphibole?). This phenomenon is observed in all samples, the surface layer down to 400 meters.

Table 5 shows the proportions of fractions less than 1 $\mu \mathrm{m}, 1$ to $10 \mu \mathrm{m}$, and greater than $10 \mu \mathrm{m}$ in weight per cent. Toward the bottom of the hole the sediments tend to become coarser owing to the increase of fractions greater than $10 \mu \mathrm{m}$.

We studied four samples - brown, black, green, and carbonate - from a tectonically fractured zone in Hole 434B, Core 15, Section 3. All specimens consist of amorphous phase, quartz, and feldspar. Clay minerals - illite, chlorite, and mixed-layer expanding minerals occur as admixtures.

\section{Site $\mathbf{4 3 5}$}

In the Pliocene-Pleistocene sediments recovered from the slope of the Japan Trench, clay minerals in the fraction less than $1 \mu \mathrm{m}$ contain mixed-layer illite-montmorillonite, illite, chlorite, kaolinite, and admixtures of mixed-layer chlorite-montmorillonite. Quartz, feldspar, and carbonate occur in trace amounts. Amorphous matter occurs in small quantities in almost all samples (Table 6, Figure 4).

The less than $1 \mu \mathrm{m}$ clay fraction consists mainly of mixed-layer illite-montmorillonite and illite. The average mixed-layer mineral content is 45 to 55 per cent. We observed two varieties of expanding beds in mixed-layer mineral, montmorillonite and Fe-montmorillonite, which occur in a stable proportion throughout (Table 7).

Illites are dioctahedral $\mathrm{Fe}-\mathrm{Al}$ varieties of $2 \mathrm{M}_{1}$ and $1 \mathrm{M}$ polytypes. The $2 \mathrm{M}_{1}$ polytype prevails (Table 8 ), though less so than in the upper-Pliocene-Pleistocene sediments at Site 434 . There is a relative downward rise in $1 \mathrm{M}$ polytype content. Average illite content is 30 per cent. The less than $1 \mu \mathrm{m}$ fraction contains an average of 15 per cent chlorite and kaolinite. Infrared spectra and

TABLE 5

Grain-Size Determination from DSDP Holes 434 and 434B

\begin{tabular}{|c|c|c|c|c|c|c|}
\hline Section & $\begin{array}{l}\text { Sub-bottom } \\
\text { Depth } \\
\text { (m) }\end{array}$ & Lithology & Age & $\underset{(\%)}{<1 \mu \mathrm{m}}$ & $\begin{array}{c}1-10 \mu \mathrm{m} \\
(\%)\end{array}$ & $\begin{array}{c}>10 \mu \mathrm{m} \\
(\%)\end{array}$ \\
\hline $\begin{array}{l}434-4-1 \\
434-7-1 \\
434-9-1\end{array}$ & $\begin{array}{l}26.0 \\
55.0 \\
74.0\end{array}$ & $\begin{array}{l}\text { Unit } 1 \\
\text { Diatomaceous } \\
\text { ooze }\end{array}$ & $\begin{array}{l}\text { Lower } \\
\text { Pliocene to } \\
\text { upper } \\
\text { Pliocene } \\
\text { and upper } \\
\text { Pleistocene }\end{array}$ & $\begin{array}{l}22.5 \\
21.4 \\
17.9\end{array}$ & $\begin{array}{l}45.7 \\
35.4 \\
29.1\end{array}$ & $\begin{array}{l}31.8 \\
43.2 \\
53.0\end{array}$ \\
\hline $\begin{array}{l}434-12-1 \\
434-16-1 \\
434-23-1 \\
434-28-1 \\
434-31-1 \\
\end{array}$ & $\begin{array}{l}102.0 \\
140.0 \\
206.0 \\
254.0 \\
282.5\end{array}$ & \begin{tabular}{l}
\multicolumn{1}{c}{ Unit 2} \\
Diatomaceous \\
mudstone
\end{tabular} & $\begin{array}{l}\text { Lower } \\
\text { Pliocene }\end{array}$ & $\begin{array}{r}23.9 \\
21.9 \\
15.9 \\
23.3 \\
9.2 \\
\end{array}$ & $\begin{array}{l}44.0 \\
47.9 \\
48.7 \\
30.7 \\
35.9 \\
\end{array}$ & $\begin{array}{l}32.1 \\
30.2 \\
35.4 \\
45.9 \\
54.9 \\
\end{array}$ \\
\hline $\begin{array}{l}434 \mathrm{~B}-8-2 \\
434 \mathrm{~B}-16-3\end{array}$ & $\begin{array}{l}354.0 \\
432.0\end{array}$ & $\begin{array}{l}\quad \text { Unit } 3 \\
\text { Diatomaceous } \\
\text { vitric mud- } \\
\text { stone }\end{array}$ & $\begin{array}{l}\text { Lower } \\
\text { Pliocene }\end{array}$ & $\begin{array}{l}17.5 \\
23.8\end{array}$ & $\begin{array}{l}44.0 \\
38.7\end{array}$ & $\begin{array}{l}38.5 \\
37.5\end{array}$ \\
\hline $\begin{array}{l}434 \mathrm{~B}-19-2 \\
434 \mathrm{~B}-24-2 \\
434 \mathrm{~B}-28-1 \\
434 \mathrm{~B}-33-1 \\
434 \mathrm{~B}-34-2 \\
434 \mathrm{~B}-34-2 \\
\end{array}$ & $\begin{array}{l}458.0 \\
507.0 \\
543.0 \\
591.0 \\
601.0 \\
601.5 \\
\end{array}$ & $\begin{array}{c}\text { Unit } 4 \\
\text { Tuffite }\end{array}$ & $\begin{array}{l}\text { Upper } \\
\text { Miocene }\end{array}$ & $\begin{array}{r}18.9 \\
23.6 \\
9.8 \\
12.0 \\
22.2 \\
16.1 \\
\end{array}$ & $\begin{array}{l}33.8 \\
41.5 \\
33.3 \\
47.6 \\
45.3 \\
25.0 \\
\end{array}$ & $\begin{array}{l}47.3 \\
34.9 \\
56.9 \\
40.4 \\
32.5 \\
58.9 \\
\end{array}$ \\
\hline $434 \mathrm{~B}-37-1$ & 628.0 & $\begin{array}{l}\quad \text { Unit } 5 \\
\text { Diatomaceous } \\
\text { vitric mud- } \\
\text { stone }\end{array}$ & $\begin{array}{l}\text { Uppet } \\
\text { Miocene }\end{array}$ & 11.7 & 26.5 & 61.7 \\
\hline
\end{tabular}

X-ray diffraction analyses showed as much as 5 per cent kaolinite. Chlorite throughout the site is of the trioctahedral variety and often contains a few expanding interlayers. Chlorite with a watered brucitic layer is rare.

The 1 to $10 \mu \mathrm{m}$ fraction contains the same clay mineral complex as the less than $1 \mu \mathrm{m}$ fraction. Table 6 presents clay mineral proportions: quartz, feldspar, and amorphous phase increase sharply, and exhibit amphibole whereas carbonate and kaolinite almost disappear. The Z-coefficient is the same as for the less than $1 \mu \mathrm{m}$ fraction of mixed-layer mineral (Table 6). Dioctahedral minerals in the 1 to $10 \mu \mathrm{m}$ fraction are more enriched in iron, because the relative increase of the $b$-parameter (Table 9) better dissolves $17 \AA$. Table 10 shows the proportions for fractions less than $1 \mu \mathrm{m}, 1$ to $10 \mu \mathrm{m}$, and greater than $10 \mu \mathrm{m}$.

\section{Site 436}

The composition and distribution of clay and coexisting minerals from sediments drilled at Site 436 (Table 11, Figure 5) suggest two contrasting rock masses: upper and lower. In the lower rock mass (Units 5 and 6), the less than $1 \mu \mathrm{m}$ fraction is composed mainly of $17-\AA$ mineral. The amounts and composition of expanding minerals in this rock mass vary (Table 12). Sediments enriched in montmorillonite contain beds with mixedlayer illite-montmorillonitic mineral and Fe-montmorillonite. Fe-montmorillonite is found in green clay, which contains fragments of calcareous fossils (Sample 43641-1, 34-36 cm). Montmorillonite in all cases has a $b$-parameter equal to $9.01 \AA$ (Table 13). It is barely affected by hot 10 per cent $\mathrm{HCl}$. Expanding beds of mixedlayer mineral are of two types, montmorillonite and $\mathrm{Fe}$ montmorillonite; the $b$-parameter of the latter is $9.05 \AA$ (Table 13).

Illite is present in all samples from the lower rock mass. In the fraction less than $1 \mu \mathrm{m}$ it ranges from 4 to 26 per cent and averages 20 per cent. It is of the dioctahedral $\mathrm{Fe}-\mathrm{Al}$ variety, with $2 \mathrm{M}_{1}$ and $1 \mathrm{M}$ polytypes (Table 14).

There is no chlorite in the less than $1 \mu \mathrm{m}$ fraction. In the lower rock mass, the $7-\AA$ minerals are represented by kaolinite only (Figure 5). Kaolinite plates have oval or uneven margins (Plate 1, Figure 4). Mixed-layer chlorite-montmorillonite, feldspar, and amorphous phase are absent. One sample only contains traces of carbonate. Thus, the less than $1 \mu \mathrm{m}$ fraction from the lower rock mass sediments is composed of 17 - $\AA$ minerals, and small quantities of illite and kaolinite, and traces of quartz. Electron microscopy (Plate 2) and electron diffraction (Table 13) analyses revealed palygorskite crystals in the less than $1 \mu \mathrm{m}$ fraction. Palygorskite-sepiolitic minerals disappeared in the 1 to $10 \mu \mathrm{m}$ fraction, whereas quartz and feldspar increased (Table 11). X-ray diffraction analysis determined clinoptilolite by intensive $8.94-\AA$ reflection in one sample. That montmorillonite from Units 5 and 6 have an increased $b$-parameter (Table 13) and dissolve more easily in 10 per cent $\mathrm{HCl}$ solution indicates that larger montmorillonitic crystals belong to the $\mathrm{Fe}$-montmorillonite group. 


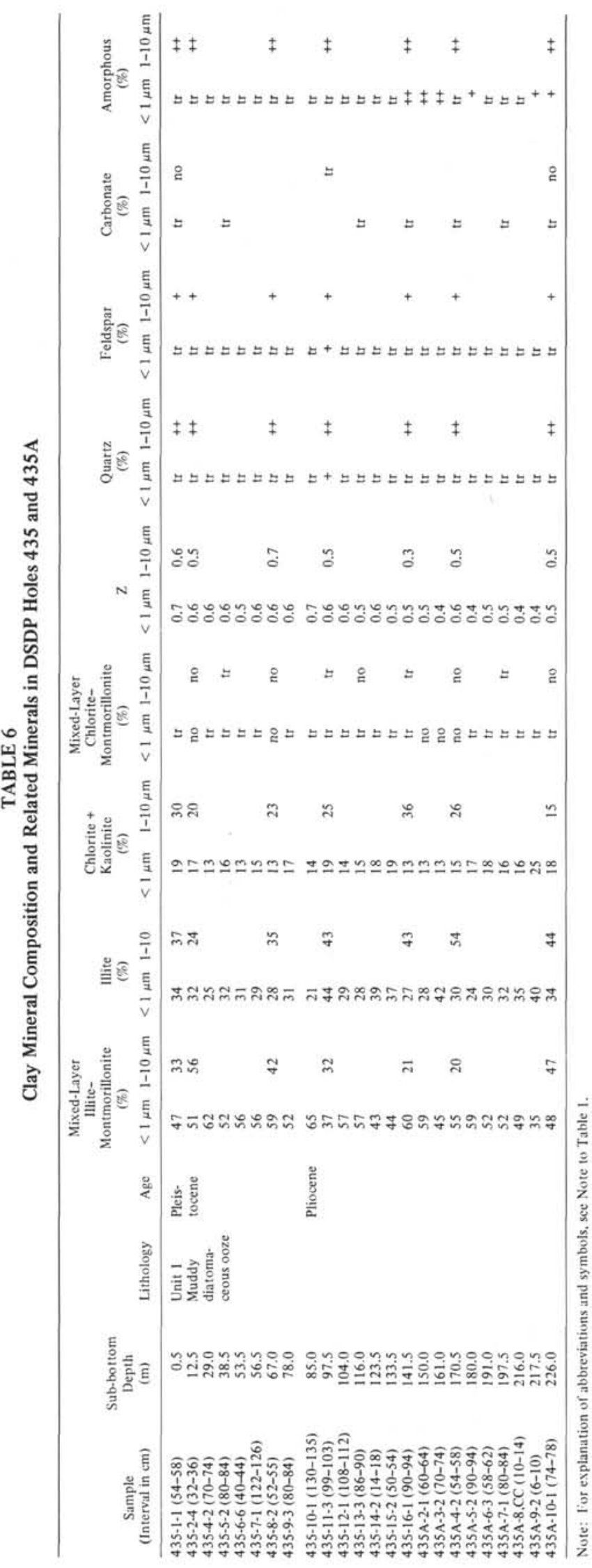

The less than $1 \mu \mathrm{m}$ fraction in the upper rock mass of Pliocene-Holocene sediments (Units 1 and 2, Sub-unit $3 \mathrm{~A}$, and the upper part of Unit 3 ) is composed of the same clay and coexisting minerals as in the Pliocene sediments recovered in the Japan Trench at Site 434. Mixed-layer illite-montmorillonite together with illite is dominant (Table 11). Mixed-layer chlorite-montmorillonite, feldspar, and carbonate occur in trace amounts. Quartz increases toward the bottom of the upper rock mass. Amorphous phase is unevenly distributed, and in some places increases in content (Table 11). An admixture of sepiolite-palygorskite minerals is revealed in the upper part of the upper rock mass by a weak ring at 11.5 to $12 \AA$.

Mixed-layer illite-montmorillonite content in the less than $1 \mu \mathrm{m}$ fraction averages 40 to 45 per cent and varies by a maximum of 28 to 31 per cent. Expanding interlayers are composed mainly of Fe-montmorillonite. Femontmorillonite-to-montmorillonite ratio changes downward throughout the site because of the increase of montmorillonitic layers.

Illite is the dioctahedral $\mathrm{Fe}-\mathrm{Al}$ variety with a prevailing $2 \mathrm{M}_{1}$ polytype throughout the upper rock mass (Table 14). Average illite content is 35 to 40 per cent, with maximum variations of 26 to 51 per cent.

Chlorite in mixture with kaolinite constitutes 15 to 20 per cent in the less than $1 \mu \mathrm{m}$ fraction. Kaolinite content is about 5 per cent.

Quartz, carbonate, and feldspar increase in the 1 to $10 \mu \mathrm{m}$ fraction (Table 11) and exhibit amphibole (8.3 $\AA$ ).

Between the lower and the upper rock masses there is a passage bed of Miocene sediments. It contains mineralogical features of both the upper and the lower rock masses, its lower (Unit 4) and upper parts characterized by the features of the lower and upper rock mass, respectively. Similarities between the lower rock mass and the lower part of the passage bed are increased $17-\AA$ mineral content in the less than $1 \mu \mathrm{m}$ fraction, increased montmorillonitic content in the 17 - $\AA$ mineral, a relatively small illite content unaffected by 10 per cent $\mathrm{HCl}$ treatment, absence or scarcity of chlorite, and the presence of palygorskite. Similarities to the upper rock mass are replacement of montmorillonite for mixed-layer illite-montmorillonitic mineral and increased illite and chlorite content. The 1 to $10 \mu \mathrm{m}$ fraction in passage bed sediments compared to the same fraction in upper rock mass sediments contains more 17 - $\AA$ mineral (Table 11).

The proportions for fractions less than $1 \mu \mathrm{m}, 1$ to 10 $\mu \mathrm{m}$, and greater than $10 \mu \mathrm{m}$ (weight per cent) of Cretaceous-Holocene sediments recovered from Site 436 are given in Table 15.

We studied three interlayers of vitric ash in sediments recovered from Site 436 at 1.8 meters (Sample 436-1-2, 29-31 cm), 76.8 meters (Sample 436-9-2, 82-86 cm), and 303.5 meters (Sample 436-33-1, 98-100 cm). These interlayers contain 85 to 95 per cent volcanic glass. The X-ray diffraction patterns of vitric ashes show mainly amorphous phase, quartz, and feldspar. In Samples $436-1-2,29-31 \mathrm{~cm}$, and 436-33-1, 98-100 cm, 17- $\AA$ mineral, illite, and chlorite are hardly detectable. An admix- 


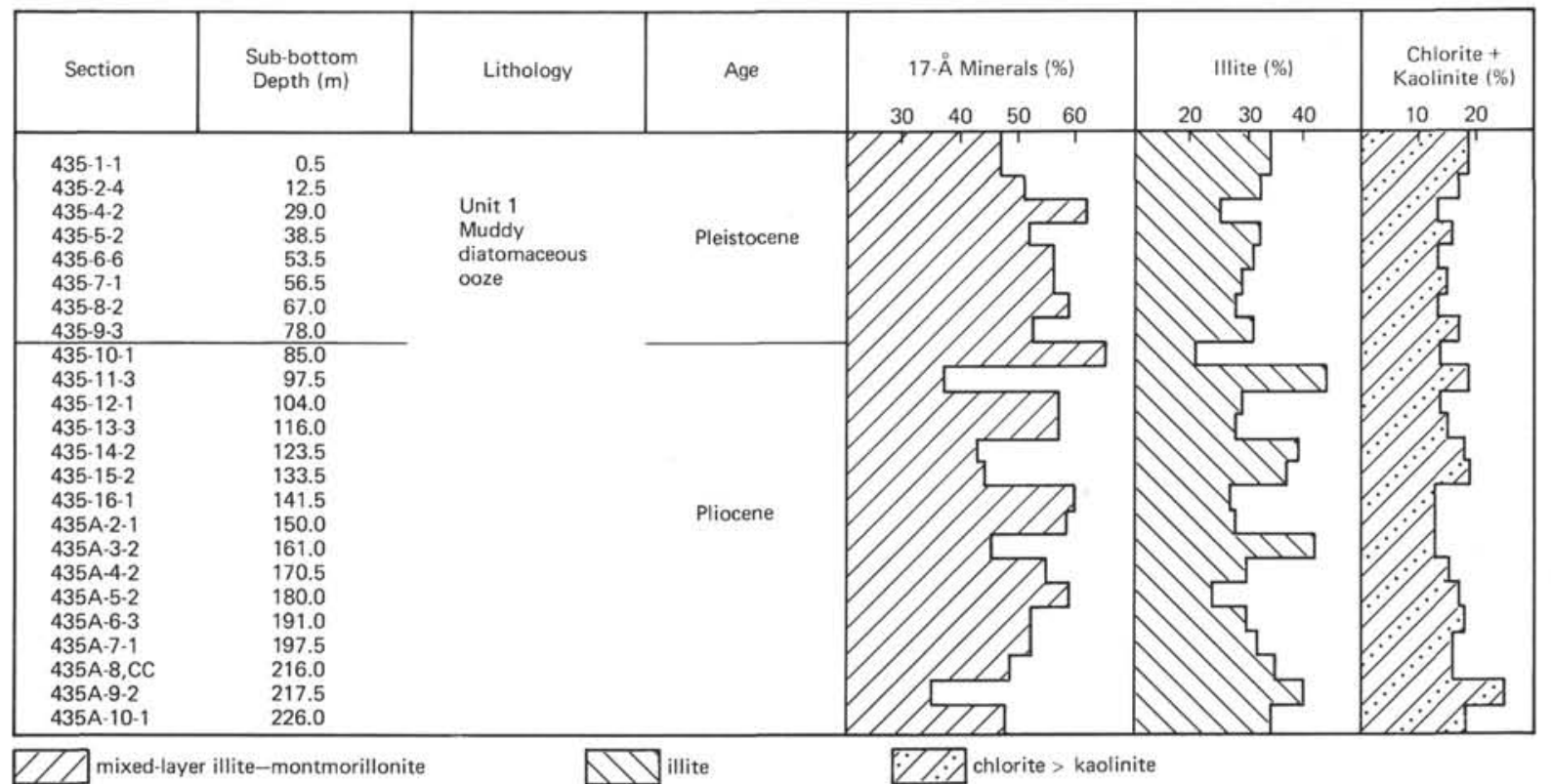

Figure 4. Variations in clay minerals composition of the less than $1 \mu \mathrm{m}$ fraction from Site 435.

TABLE 7

Sample Tests from DSDP Holes 435 and 435A

\begin{tabular}{|c|c|c|c|c|c|c|c|}
\hline \multirow[b]{2}{*}{ Section } & \multirow{2}{*}{$\begin{array}{l}\text { Sub-bottom } \\
\text { Depth } \\
\text { (m) }\end{array}$} & \multirow[b]{2}{*}{ Lithology } & \multirow[b]{2}{*}{ Age } & \multicolumn{2}{|c|}{$\begin{array}{c}10 \% \mathrm{HC} 1 \\
1 \text { hour at } 90-100^{\circ} \mathrm{C}\end{array}$} & \multicolumn{2}{|c|}{$\begin{array}{c}1 \mathrm{~N} \mathrm{MgCl} 2 \\
\text { ethylene glycol }\end{array}$} \\
\hline & & & & $<1 \mu \mathrm{m}$ & $1-10 \mu \mathrm{m}$ & $<1 \mu \mathrm{m}$ & $1-10 \mu \mathrm{m}$ \\
\hline $435-1-1$ & 0.5 & $\begin{array}{l}\text { Unit } 1 \\
\text { Muddy Diato- } \\
\text { maceous ooze }\end{array}$ & Pleistocene & $\mathrm{Fe}-\mathrm{m} \approx \mathrm{m}$ & $\mathrm{Fe}-\mathrm{m}>\mathrm{m}$ & no verm & no verm \\
\hline $435-8-2$ & 67.0 & & & $\mathrm{Fe}-\mathrm{m} \approx \mathrm{m}$ & & & \\
\hline $\begin{array}{l}435-11-3 \\
435-16-1 \\
435-10-1\end{array}$ & $\begin{array}{r}97.0 \\
141.5 \\
226.0\end{array}$ & & Pliocene & $\begin{array}{l}\mathrm{Fe}-\mathrm{m} \approx \mathrm{m} \\
\mathrm{Fe}-\mathrm{m} \approx \mathrm{m}\end{array}$ & $\begin{array}{l}\mathrm{Fe}-\mathrm{m}>\mathrm{m} \\
\mathrm{Fe}-\mathrm{m}>\mathrm{m} \\
\mathrm{Fe}-\mathrm{m}>\mathrm{m}\end{array}$ & $\begin{array}{l}\text { no verm } \\
\text { no verm } \\
\text { no verm }\end{array}$ & $\begin{array}{l}\text { no verm } \\
\text { no verm } \\
\text { no verm }\end{array}$ \\
\hline
\end{tabular}

Note: $\mathrm{Fe}-\mathrm{m}=\mathrm{Fe}-\mathrm{mon}$ tmorillonite, $\mathrm{m}=$ montmorillonite, verm $=$ vermiculite .

TABLE 8

Poly types of Illite in DSDP Holes 435 and $435 A$

\begin{tabular}{|c|c|c|c|c|c|c|}
\hline \multirow[b]{2}{*}{ Section } & \multirow{2}{*}{$\begin{array}{l}\text { Sub-bottom } \\
\text { Depth } \\
\text { (m) }\end{array}$} & \multirow[b]{2}{*}{ Lithology } & \multirow[b]{2}{*}{ Age } & \multicolumn{2}{|c|}{ Polytype } & \multirow[b]{2}{*}{ Comments } \\
\hline & & & & $<1 \mu \mathrm{m}$ & $1-10 \mu \mathrm{m}$ & \\
\hline $435-1-1$ & 0.5 & $\begin{array}{c}\text { Unit 1 } \\
\text { Muddy Diato- } \\
\text { maceous ooze }\end{array}$ & Pleistocene & $2 \mathrm{M}_{1}>1 \mathrm{M}$ & $2 \mathrm{M}_{1}>1 \mathrm{M}$ & 1M decrease \\
\hline $435-5-2$ & 38.5 & & & $2 \mathrm{M}_{1}>1 \mathrm{M}$ & & \\
\hline $\begin{array}{l}435-11-3 \\
435-13-3 \\
435-16-1 \\
435 A-4-2 \\
435 A-7-1 \\
435 A-10-1\end{array}$ & $\begin{array}{r}97.5 \\
116.0 \\
141.5 \\
170.5 \\
197.5 \\
226.0\end{array}$ & & Pliocene & $\begin{array}{l}2 \mathrm{M}_{1}>1 \mathrm{M} \\
2 \mathrm{M}_{1}>1 \mathrm{M} \\
2 \mathrm{M}_{1}>1 \mathrm{M} \\
2 \mathrm{M}_{1}>1 \mathrm{M} \\
2 \mathrm{M}_{1}>1 \mathrm{M} \\
2 \mathrm{M}_{1}>1 \mathrm{M}\end{array}$ & $?$ & \\
\hline
\end{tabular}

ture of these minerals is more clearly observed in Sample 436-9-2, 82-86 cm.

\section{CHEMICAL COMPOSITION OF $<1 \mu \mathrm{m}$ FRACTIONS}

Table 16 presents data from the chemical analysis of the less than $1 \mu \mathrm{m}$ fraction. There is an increased $\mathrm{SiO}_{2}$ content at Sites 434 and $435 . \mathrm{SiO}_{2}$ in the less than $1 \mu \mathrm{m}$ fraction is evenly distributed throughout the sediment.
TABLE 9

The $b$-Parameter in DSDP Holes 435 and 435A

\begin{tabular}{|c|c|c|c|c|c|}
\hline \multirow[b]{2}{*}{ Section } & \multirow{2}{*}{$\begin{array}{l}\text { Sub-bottom } \\
\text { Depth } \\
\text { (m) }\end{array}$} & \multirow[b]{2}{*}{ Lithology } & \multirow[b]{2}{*}{ Age } & \multicolumn{2}{|c|}{ b-Parameter ( $\mathrm{A})$} \\
\hline & & & & $<1 \mu \mathrm{m}$ & $1-10 \mu \mathrm{m}$ \\
\hline $435-1-1$ & 0.5 & $\begin{array}{c}\text { Unit 1 } \\
\text { Muddy diato- }\end{array}$ & Pleistocene & $\begin{array}{l}b_{1}=9.04 \\
b_{2}=9.25\end{array}$ & $\begin{array}{l}b_{1}=9.04 \\
b_{2}=9.25\end{array}$ \\
\hline $435-5-2$ & 38.5 & maceous ooze & & $\begin{array}{l}b_{1}=9.02 \\
b_{2}=9.25\end{array}$ & \\
\hline $435-11-3$ & 97.5 & & Pliocene & $\begin{array}{l}b_{1}=9.00 \\
b_{2}=9.25\end{array}$ & $\begin{array}{l}b_{1}=9.03 \\
b_{2}=9.25\end{array}$ \\
\hline $435-13-3$ & 116.0 & & & $\begin{array}{l}b_{1}=9.01 \\
b_{2}=9.25\end{array}$ & \\
\hline $435-16-1$ & 141.5 & & & $\begin{array}{l}b_{1}=9.01 \\
b_{2}=9.25\end{array}$ & \\
\hline $435 \mathrm{~A}-4-2$ & 170.5 & & & $\begin{array}{l}b_{1}=9.02 \\
b_{2}=9.25\end{array}$ & \\
\hline $435 \mathrm{~A}-7-1$ & 197.5 & & & $\begin{array}{l}b_{1}=9.00 \\
b_{2}=9.25\end{array}$ & \\
\hline $435 \mathrm{~A}-10-1$ & 226.0 & & & $\begin{array}{l}b_{1}^{2}=9.01 \\
b_{2}=9.25\end{array}$ & $\begin{array}{l}b_{1}=9.03 \\
b_{2}=9.24\end{array}$ \\
\hline
\end{tabular}

At $\mathrm{Site} 436, \mathrm{SiO}_{2}$ content decreases downward from the upper to the lower rock mass.

At Site 434, the chemical composition of the less than $1 \mu \mathrm{m}$ fraction shows no tendency to downward change, 
TABLE 10

Grain-Size Determination from DSDP Holes 435 and 435A

\begin{tabular}{lcccccc}
\hline Section & $\begin{array}{c}\text { Sub-bottom } \\
\text { Depth } \\
(\mathrm{m})\end{array}$ & Lithology & Age & $\begin{array}{c}<1 \mu \mathrm{m} \\
(\%)\end{array}$ & $\begin{array}{c}1-10 \mu \mathrm{m} \\
(\%)\end{array}$ & $\begin{array}{c}10 \mu \mathrm{m} \\
(\%)\end{array}$ \\
\hline $435-1-1$ & 0.5 & Unit 1 & Pleistocene & 13.1 & 34.6 & 52.3 \\
$435-2-4$ & 12.5 & Muddy diato- & & 23.4 & 31.0 & 45.6 \\
$435-5-2$ & 38.5 & maceous ooze & & 19.8 & 35.3 & 44.9 \\
$435-8-2$ & 67.0 & & & 11.5 & 19.3 & 69.2 \\
$435-11-3$ & 97.5 & & Pliocene & 20.0 & 46.8 & 33.2 \\
$435-13-3$ & 116.0 & & & 23.1 & 54.3 & 22.5 \\
$435-16-1$ & 141.5 & & & 17.2 & 61.7 & 21.1 \\
$435 \mathrm{~A}-4-2$ & 170.5 & & & 17.3 & 57.0 & 25.7 \\
$435 \mathrm{~A}-7-1$ & 197.5 & & & 13.2 & 56.6 & 30.2 \\
$435 \mathrm{~A}-10-1$ & 226.0 & & 16.6 & 55.8 & 27.6 \\
\hline
\end{tabular}

whereas at Site 436 it does change: $\mathrm{Fe}_{2} \mathrm{O}_{3}, \mathrm{MnO}, \mathrm{MgO}$ increases, and $\mathrm{FeO}$ and $\mathrm{Na}_{2} \mathrm{O}$ are reduced.

\section{MICROELEMENTS IN $<1 \mu$ m AND 1 TO $10 \mu \mathrm{m}$ FRACTIONS}

Tables of microelement distribution $(\mathrm{Co}, \mathrm{Ni}, \mathrm{Ag}, \mathrm{Zn}$, $\mathrm{V}, \mathrm{Sn}, \mathrm{Cr}, \mathrm{Pb}, \mathrm{B}$, and $\mathrm{Cu}$ ) in fractions less than $1 \mu \mathrm{m}, 1$ to $10 \mu \mathrm{m}$, greater than $10 \mu \mathrm{m}$, and bulk are presented by Murdmaa et al. (this volume). In sediments recovered from Sites 434, 435, and 436 (upper rock mass only), $\mathrm{Co}, \mathrm{Ni}, \mathrm{Zn}, \mathrm{V}, \mathrm{Sn}, \mathrm{Cr}, \mathrm{B}$, and $\mathrm{Cu}$ are distributed rather evenly, whereas distribution of $\mathrm{Ag}, \mathrm{Zn}$, and $\mathrm{Pb}$ is somewhat abnormal. High Ag content is found in the less than $1 \mu \mathrm{m}$ fraction in Hole 434B. Abnormally high $\mathrm{Pb}$ content is observed in all fractions (Sample 435-8-2, $52-55 \mathrm{~cm}$ ).

In lower rock mass and passage bed (its lower part particularly) sediments at Site $436, \mathrm{Co}, \mathrm{Ni}, \mathrm{Zn}, \mathrm{V}$, and $\mathrm{Cu}$ content in the less than $1 \mu \mathrm{m}$ and 1 to $10 \mu \mathrm{m}$ fractions is increased compared with the upper rock mass. Sn is distributed evenly throughout the site. The highest $\mathrm{Ag}$ content is found in the upper part of the passage bed. $\mathrm{Cr}$ and $\mathrm{B}$ are distributed rather evenly. In a sample from the lower part of the passage bed, there was abnormally high $\mathrm{Pb}$ content.

In most cases the highest microelement content was found in the less than $1 \mu \mathrm{m}$ fraction.

\section{DISCUSSION}

\section{Origin of Clay Minerals}

\section{Terrigenous Origin}

Our data show that clay minerals from the sediments drilled at Sites 434 and 435 and from the PlioceneHolocene sediments at Site 436 are terrigenous. First of all, they are abundant in illite of the $2 \mathrm{M}_{1}$ polytype, produced during epigenesis or metamorphism. The $2 \mathrm{M}_{1}$ polytype undoubtedly derived from land source areas. Clay of mixed-layer illite-montmorillonite, illite, and chlorite, with a kaolinite admixture as well as with accompanying minerals (quartz and feldspar), is typical of terrigenous oceanic sediments and has been studied in detail in the surface layer of Pacific sediments (Rateev et al., 1966; Griffin et al., 1968; Gorbunova, 1970; Lisitsyna et al., 1973).

Fractions of 1 to $10 \mu \mathrm{m}$ as compared with those of less than $1 \mu \mathrm{m}$ contain more quartz and feldspar, which is characteristic of terrigenous sediments.
Diagenesis does not significantly affect clay mineral composition in Pliocene-Holocene sediments. Variations with depth in relative amounts of minerals in clay fractions throughout the sections are consistent with a terrigenous origin.

The crystalline structure of clay minerals does not change with sediment thickness. The structure of disordered mixed-layer illite-montmorillonite is uniform, as is the unstable structure of chlorite. Expanding layers and hydrated brucitic layers occur in the chlorite throughout Holes 434B and 435A and at the bottom of the upper rock mass of Hole 436. Mixed-layer chloritemontmorillonite and kaolinite occur as admixtures in all boreholes studied. Terrigeneous mixed-layer chloritemontmorillonite is widespread in Recent sediments ( $\mathrm{Li}$ sitsyna et al., 1973; Kurnosov and Murdmaa, 1976).

Illite as well as chlorite are stable in the sections investigated. The relative increase of polytype $1 \mathrm{M}$ downward at Sites 434 and 435 may reflect both the changes in source areas and the diagenetic synthesis of these illites as glauconite.

However, we found that illitic layers in the mixedlayer illite-montmorillonite tend to increase downward. The Z-coefficient reflects this increase (Tables 2, 7, 12). Substitution of expanding spacings by illitic ones in a mixed-layer mineral is most prominent in sediments from Sites 434 and 435 . Tectonic deformations probably accelerate the process of micatization of $17-\AA$ mineral in sediments from Site 434.

Thus in terrigenous sediments (Sites 434 and 435 ) as well as in the Pliocene-Holocene sediments from Site 436 , clay minerals are of terrigenous origin and stable against transformation. Diagenetic influence on clay minerals results only in a relative increase of illitic layers in 17 - $\AA$ mixed-layer mineral - that is, in an increase of K.

\section{Authigenic Origin}

We propose an authigenic origin for the clay minerals (montmorillonite and $\mathrm{Fe}$-montmorillonite) in pelagic clays and, in part, of the passage bed at Site 436 . The lack of impurities both structural (layers of mica) and mechanical (quartz, feldspar, carbonate, and amorphous phase) indicate their origin in situ. Trioctahedral minerals are absent. Clinoptilolite and palygorskite coexisting with montmorillonite and Fe-montmorillonite are typical authigenic minerals. Scanning electron microscope photomicrographs indicate that the textural patterns of pelagic clays differ from those of terrigenous sediments (Plates 3, 4). Clinoptilolite occurs in cavities or in clay groundmass (Plate 4, Figure 3). Palygorskite is formed after montmorillonite (Plate 4, Figures 5 and 6). A. P. Lisitsen et al. (1971) has determined that palygorskite in Cretaceous pelagic clays was formed authigenically in magnesium-rich solutions at Sites 47,50 , and 51, which are east and southeast of Site 436. H. Okada (Okada and Tomita, 1973) also considers palygorskite from Leg 20 sediments to be authigenic.

The minerals investigated were probably formed from volcanic glass. Plate 4, Figures 1 and 2, shows montmorillonite to be an alteration product of palag- 
TABLE 11

Clay Mineral Composition and Related Minerals in DSDP Hole 436

\begin{tabular}{|c|c|c|c|c|c|c|c|c|c|c|c|}
\hline \multirow{2}{*}{$\begin{array}{c}\text { Sample } \\
\text { (Interval in } \mathrm{cm} \text { ) }\end{array}$} & \multirow{2}{*}{$\begin{array}{l}\text { Sub-bottom } \\
\text { Depth } \\
\text { (m) }\end{array}$} & \multirow[b]{2}{*}{ Lithology } & \multirow[b]{2}{*}{ Age } & \multicolumn{2}{|c|}{$\begin{array}{c}\text { Mixed-Layer } \\
\text { Illite- } \\
\text { Montmorillonite } \\
(\%)\end{array}$} & \multicolumn{2}{|c|}{$\begin{array}{l}\text { Montmorillonite } \\
(\%)\end{array}$} & \multicolumn{2}{|c|}{$\begin{array}{r}\text { Illite } \\
(\%)\end{array}$} & \multicolumn{2}{|c|}{$\begin{array}{c}\text { Chlorite + } \\
\text { Kaolinite } \\
(\%)\end{array}$} \\
\hline & & & & $<1 \mu \mathrm{m}$ & $1-10 \mu \mathrm{m}$ & $<1 \mu \mathrm{m}$ & $1-10 \mu \mathrm{m}$ & $<1 \mu \mathrm{m}$ & $1-10 \mu \mathrm{m}$ & $<1 \mu \mathrm{m}$ & $1-10 \mu \mathrm{m}$ \\
\hline $436-1-3(20-25)$ & 3.0 & Unit 1 & Holocene & 50 & 14 & & & 34 & 62 & 16 & 24 \\
\hline $436-2-2(110-114)$ & 10.5 & Vitric & to late & 40 & & & & 40 & & 20 & \\
\hline $436-3-4(87-89)$ & 21.0 & diatoma- & Pliocene & 36 & & & & 43 & & 21 & \\
\hline $436-4-1(30-32)$ & 27.0 & ceous & & 38 & & & & 42 & & 20 & \\
\hline $436-4-2(80-84)$ & 29.0 & mud & & 59 & & & & 27 & & 14 & \\
\hline $436-5-3(14-18)$ & 39.5 & & & 36 & & & & 43 & & 21 & \\
\hline $436-6-3(30-34)$ & 49.0 & & & 42 & & & & 38 & & 20 & \\
\hline $436-7-3(20-24)$ & 58.5 & & & 37 & & & & 45 & & 18 & \\
\hline $436-8-2(32-36)$ & 66.5 & & & 45 & & & & 37 & & 18 & \\
\hline $436-9-2(82-86)$ & 76.5 & & & 38 & & & & 41 & & 21 & \\
\hline $436-9-2(120-125)$ & 77.0 & & & 41 & 32 & & & 37 & 47 & 22 & 21 \\
\hline $436-10-3(75-80)$ & 87.5 & & & 39 & & & & 37 & & 24 & \\
\hline $436-11-6(95-99)$ & 101.5 & & & 54 & & & & 31 & & 15 & \\
\hline $436-12-1(106-110)$ & 104.0 & Unit 2 & Pliocene & 61 & & & & 26 & & 13 & \\
\hline $436-13-4(30-34)$ & 117.0 & Vitric & & 30 & & & & 51 & & 19 & \\
\hline $436-14-4(4-8)$ & 126.5 & diatoma- & & 48 & & & & 37 & & 15 & \\
\hline $436-15-4(60-64)$ & 136.5 & ceous & & 39 & 40 & & & 44 & 44 & 17 & 16 \\
\hline $436-16-2(100-104)$ & 143.5 & ooze & & 42 & & & & 40 & & 18 & \\
\hline $436-17-4(44-48)$ & 155.0 & & & 60 & & & & 28 & & 12 & \\
\hline $436-18-2(60-64)$ & 162.0 & & & 49 & & & & 34 & & 17 & \\
\hline $436-19-1(56-60)$ & 170.0 & Sub-unit & Pliocene & 49 & & & & 34 & & 17 & \\
\hline $436-20-1(113-117)$ & 180.0 & 3a Diato- & & 28 & & & & 48 & & 24 & \\
\hline $436-21-1(114-118)$ & 189.5 & maceous & & 53 & & & & 33 & & 14 & \\
\hline $436-22-1(56-60)$ & 198.5 & vitric & & 46 & & & & 39 & & 15 & \\
\hline $436-23-2(55-59)$ & 209.5 & mud & & 46 & & & & 37 & & 17 & \\
\hline $436-25-1(70-74)$ & 227.0 & & & 40 & & & & 31 & & 29 & \\
\hline $436-26-1(12-16)$ & 236.0 & & & 41 & & & & 43 & & 16 & \\
\hline $436-27-3(60-64)$ & 249.0 & Sub-unit & Late & 46 & 46 & & & 40 & 40 & 14 & 14 \\
\hline $436-28-1(74-78)$ & 255.5 & 3b Diato- & Miocene & 57 & & & & 32 & & 11 & \\
\hline $436-29-1(80-84)$ & 265.0 & maceous & & 51 & 30 & & & 36 & 60 & 13 & 10 \\
\hline $436-31-1(33-37)$ & 283.5 & vitric & & 62 & 28 & & & 29 & 52 & 9 & 20 \\
\hline $436-31-3(65-69)$ & 287.0 & mudstone & & 53 & & & & 38 & & 9 & \\
\hline $436-32-2(58-62)$ & 295.0 & & & 55 & & & & 34 & & 11 & \\
\hline $436-33-1(56-60)$ & 303.0 & & & 37 & & & & 48 & & 15 & \\
\hline $436-34-3(60-64)$ & 315.5 & Unit 4 & Miocene & 46 & 50 & & & 42 & 40 & 12 & 10 \\
\hline $436-35-3(60-64)$ & 325.0 & Radio- & & 58 & 37 & & & 37 & 51 & 5 & 12 \\
\hline $436-36-3(50-54)$ & 334.5 & larian- & & 57 & 74 & & & 32 & 20 & 11 & 6 \\
\hline $436-37-4(80-84)$ & 345.5 & diatoma- & & 60 & & & & 31 & & 9 & \\
\hline $436-38-2(90-94)$ & 352.0 & ceous mud- & & 70 & 65 & & & 23 & 32 & 7 & 3 \\
\hline $436-38-6(90-94)$ & 358.0 & stone & & 71 & & & & 23 & & 6 & \\
\hline $436-39-2(26-30)$ & 361.0 & Unit 5 & $?$ & & & 80 & 100 & 18 & no & 2 & no \\
\hline $436-39-5(76-80)$ & 366.0 & Pelagic & & & & 67 & 61 & 25 & 31 & 8 & 8 \\
\hline $436-40-4(54-58)$ & 374.0 & clay & & 54 & 49 & no & & 36 & 40 & 10 & 11 \\
\hline $436-41-1(10-12)$ & 378.5 & Unit 6 & Creta- & & 45 & 65 & & 31 & 45 & 4 & 10 \\
\hline $436-41-1(34-36)$ & 378.5 & $\begin{array}{l}\text { Pelagic } \\
\text { clay and } \\
\text { chert }\end{array}$ & ceous & & & 87 & & 13 & & no & \\
\hline
\end{tabular}

Note: For explanation of abbreviations and symbols, see Note to Table 1.

onitized volcanic glass fragments. Similar "spongy" montmorillonite commonly covers basaltic (palagonitized) glass fragments from Pacific bottom samples (Kurnosov et al., 1976). Weaver's K-test also showed that most montmorillonite was formed from volcanic glass. G. Y. Butuzova, N. A. Lisitsyna, and B. P. Gradusov (1977), who studied the composition of clay minerals in Cretaceous red clays from Legs 16 and 17 drilling sites, drew attention to the high montmorillonite content (87-94 per cent) in beds enriched by volcanic material. They propose clay mineral and zeolite formation from dispersed volcanic glass. Our experiments showed that the chemical properties of volcanic glass are adequate for smectite formation (Kotov et al., 1978) though insufficient for the formation of zeolites and palygorskite-sepiolitic minerals. Data obtained at 1000 atmospheres pressure and at temperatures from $100^{\circ} \mathrm{C}$ up showed that additional solutions are necessary for the production of zeolites and palygorskite-sepiolitic minerals.

Thus we suggest that pelagic clay minerals were produced at Site 436 following an alteration of dispersed volcanic glasses due to poorly mineralized hydrothermal waters and (or) increased heat flow. Increased $\mathrm{MgO}$, $\mathrm{MnO}$, and $\mathrm{Fe}_{2} \mathrm{O}_{3}$ content in the less than $1 \mu \mathrm{m}$ fractions as well as relatively high $\mathrm{Co}, \mathrm{Ni}, \mathrm{Zn}, \mathrm{V}$, and $\mathrm{Cu}$ content 
TABLE 11 - Continued

\begin{tabular}{|c|c|c|c|c|c|c|c|c|c|c|c|c|c|c|}
\hline \multicolumn{2}{|c|}{$\begin{array}{c}\text { Mixed-Layer } \\
\text { Chlorite- } \\
\text { Montmorillonite } \\
(\%)\end{array}$} & \multicolumn{2}{|c|}{$\begin{array}{l}\text { Palygorskite- } \\
\text { sepiolite } \\
\left({ }^{\prime}(x)\right.\end{array}$} & \multicolumn{2}{|c|}{ Z } & \multicolumn{2}{|c|}{$\begin{array}{c}\text { Quartz } \\
(\%)\end{array}$} & \multicolumn{2}{|c|}{$\begin{array}{l}\text { Feldspar } \\
(\%)\end{array}$} & \multicolumn{2}{|c|}{$\begin{array}{c}\text { Carbonate } \\
(\%)\end{array}$} & \multicolumn{2}{|c|}{$\begin{array}{c}\text { Amorphous } \\
(\%)\end{array}$} & \multirow[b]{2}{*}{ Comments } \\
\hline$<1 \mu \mathrm{m}$ & $1-10 \mu \mathrm{m}$ & $<1 \mu \mathrm{m}$ & $1-10 \mu \mathrm{m}$ & $<1 \mu \mathrm{m}$ & $1-10 \mu \mathrm{m}$ & $<1 \mu \mathrm{m}$ & $1-10 \mu \mathrm{m}$ & $<1 \mu \mathrm{m}$ & $1-10 \mu \mathrm{m}$ & $<1 \mu \mathrm{m}$ & $1-10 \mu \mathrm{m}$ & $<1 \mu \mathrm{m}$ & $1-10 \mu \mathrm{m}$ & \\
\hline tr & no & tr & no & 0.5 & 0.5 & tr & ++ & tr & + & & no & + & ++ & Upper rock \\
\hline $\operatorname{tr}$ & & & & 0.5 & & tr & & tr & & & & + & & mass \\
\hline tr & & & & 0.5 & & tr & & tr & & & & + & & \\
\hline no & & tr & & 0.6 & & $\mathrm{tr}$ & & $\operatorname{tr}$ & & no & & tr & & \\
\hline $\mathrm{tr}$ & & & & 0.6 & & tr & & tr & & & & tr & & \\
\hline tr & & & & 0.5 & & tr & & $\mathrm{tr}$ & & & & tr & & \\
\hline tr & & & & 0.6 & & tr & & tr & & & & tr & & \\
\hline no & & & & 0.6 & & tr & & tr & & & & $\operatorname{tr}$ & & \\
\hline tr & & & & 0.6 & & tr & & tr & & & & tr & & \\
\hline tr & & $\mathrm{tr}$ & no & 0.4 & & tr & & $\operatorname{tr}$ & & & & ++ & & \\
\hline tr & no & & & 0.5 & 0.3 & $\mathrm{tr}$ & t+ & $\operatorname{tr}$ & + & tr & no & $\operatorname{tr}$ & ++ & \\
\hline tr & & & & 0.6 & & tr & & $\operatorname{tr}$ & & & & + & & \\
\hline no & & & & 0.6 & & $\mathrm{tr}$ & & tr & & & & tr & & \\
\hline tr & & & & 0.5 & & tr & & tr & & & & + & & \\
\hline tr & & & & 0.2 & & + & & tr & & & & + & & \\
\hline tr & & & & 0.4 & & $\operatorname{tr}$ & & tr & & & & + & & \\
\hline no & no & & & 0.5 & 0.4 & tr & ++ & tr & + & & & tr & ++ & \\
\hline no & & & & 0.5 & & tr & & tr & & & & + & & \\
\hline tr & & & & 0.4 & & tr & & tr & & & & + & & \\
\hline tr & & & & 0.6 & & tr & & tr & & & & tr & & \\
\hline tr & & & & 0.4 & & tr & & tr & & & & + & & \\
\hline no & & & & 0.3 & & tr & & $\operatorname{tr}$ & & & & + & & \\
\hline tr & & & & 0.4 & & + & & + & & & & + & & \\
\hline no & & & & 0.5 & & tr & & $\mathrm{tr}$ & & & & tr & & \\
\hline tr & & & & 0.4 & & t+ & & tr & & & & + & & \\
\hline tr & & & & 0.2 & & tr & & $\operatorname{tr}$ & & tr & & + & & \\
\hline $\operatorname{tr}$ & & & & 0.4 & & ++ & & tr & & & & ++ & & \\
\hline tr & tr & & no & 0.3 & 0.3 & + & ++ & tr & + & & tr & ++ & ++ & \\
\hline $\begin{array}{l}\text { tr } \\
\text { tr }\end{array}$ & & & & $\begin{array}{l}0.5 \\
0.5\end{array}$ & 0.2 & $\begin{array}{l}\text { tr } \\
++\end{array}$ & ++ & $\begin{array}{l}\mathrm{tr} \\
\mathrm{tr}\end{array}$ & + & & & $\begin{array}{l}\text { tr } \\
+\end{array}$ & ++ & $\overline{\text { Passage bed }}$ \\
\hline tr & tr & tr & & 0.5 & 0.4 & $\mathrm{tr}$ & + & tr & + & tr & & + & ++ & \\
\hline no & tr & & & 0.5 & & tr & & $\operatorname{tr}$ & & & & H+ & & \\
\hline tr & tr & $\operatorname{tr}$ & & 0.5 & & + & & tr & & & & + & & \\
\hline tr & $\mathrm{tr}$ & & & 0.3 & & tr & & tr & & & & ++ & & \\
\hline tr & & & & 0.4 & 0.4 & tr & ++ & tr & + & & & + & + & \\
\hline tr & & & & 0.4 & 0.2 & tr & ++ & $\operatorname{tr}$ & + & & & + & + & \\
\hline tr & & tr & & 0.7 & 0.6 & $\operatorname{tr}$ & + & $\operatorname{tr}$ & tr & & & + & tr & \\
\hline tr & tr & & & 0.5 & & $\operatorname{tr}$ & & tr & & & & + & & \\
\hline no & & tr & & 0.7 & 0.9 & $\operatorname{tr}$ & tr & no & tr & $\operatorname{tr}$ & & + & $\operatorname{tr}$ & \\
\hline tr & no & & no & 0.8 & & tr & & tr & & & no & + & & \\
\hline no & & tr & no & 0.9 & 0.9 & tr & tr & no & tr & no & no & no & no & Lower rock \\
\hline no & & tr & no & 0.9 & 0.8 & tr & ++ & no & + & no & no & no & tr & mass \\
\hline no & & & & 0.6 & 0.6 & $\mathrm{tr}$ & + & $\mathrm{tr}$ & $\mathrm{tr}$ & & & no & tr & \\
\hline no & $\mathrm{tr}$ & $\operatorname{tr}$ & no & 0.8 & 0.6 & $\operatorname{tr}$ & + & no & + & no & tr & no & tr & \\
\hline no & no & tr & no & 0.8 & & no & & no & & tr & tr & no & & \\
\hline
\end{tabular}

in the less than $1 \mu \mathrm{m}$ and 1 to $10 \mu \mathrm{m}$ fractions of lower rock mass sediments at this site show the formative influence of hydrothermal solutions.

Bonatti and Joehsuu (1968) have suggested that hydrothermal solutions are responsible for palygorskite formation.

In addition to authigenic minerals (Sample 436-40-4, $54-58 \mathrm{~cm}$, the less than $1 \mu \mathrm{m}$ fraction) we found clays and coexisting minerals typical of terrigenous sediments (Table 12). Kaolinite admixture in authigenic minerals may be of terrigenous origin, and illite traces of the $2 \mathrm{M}_{1}$ polytype should be attributed to terrigenous minerals.

Thus clay minerals in pelagic clays are mainly authigenic, probably because of the alteration of volcanic glass by halmyrolysis or by the influence of poorly min- eralized hydrothermal solutions and/or increased heat flow.

\section{Mixed Origin}

In the passage bed in Site 436, the terrigenous accumulation of clay minerals suppressed the authigenic formation of minerals, though the features of authigenesis are prominent at the bottom of the passage bed and can be traced to its upper units. Authigenic characteristics include high $17-\AA$ mineral content in two fractions $(<1$ $\mu \mathrm{m}$ and $1-10 \mu \mathrm{m})$, fewer micaceous layers compared to overlying terrigenous sediments, higher kaolinite content compared with chlorite, and the occurrence of palygorskite-sepiolitic minerals and sediment texture (Plate 3 , Figures 2 and 3). Zeolites also occur in this bed (Plate 


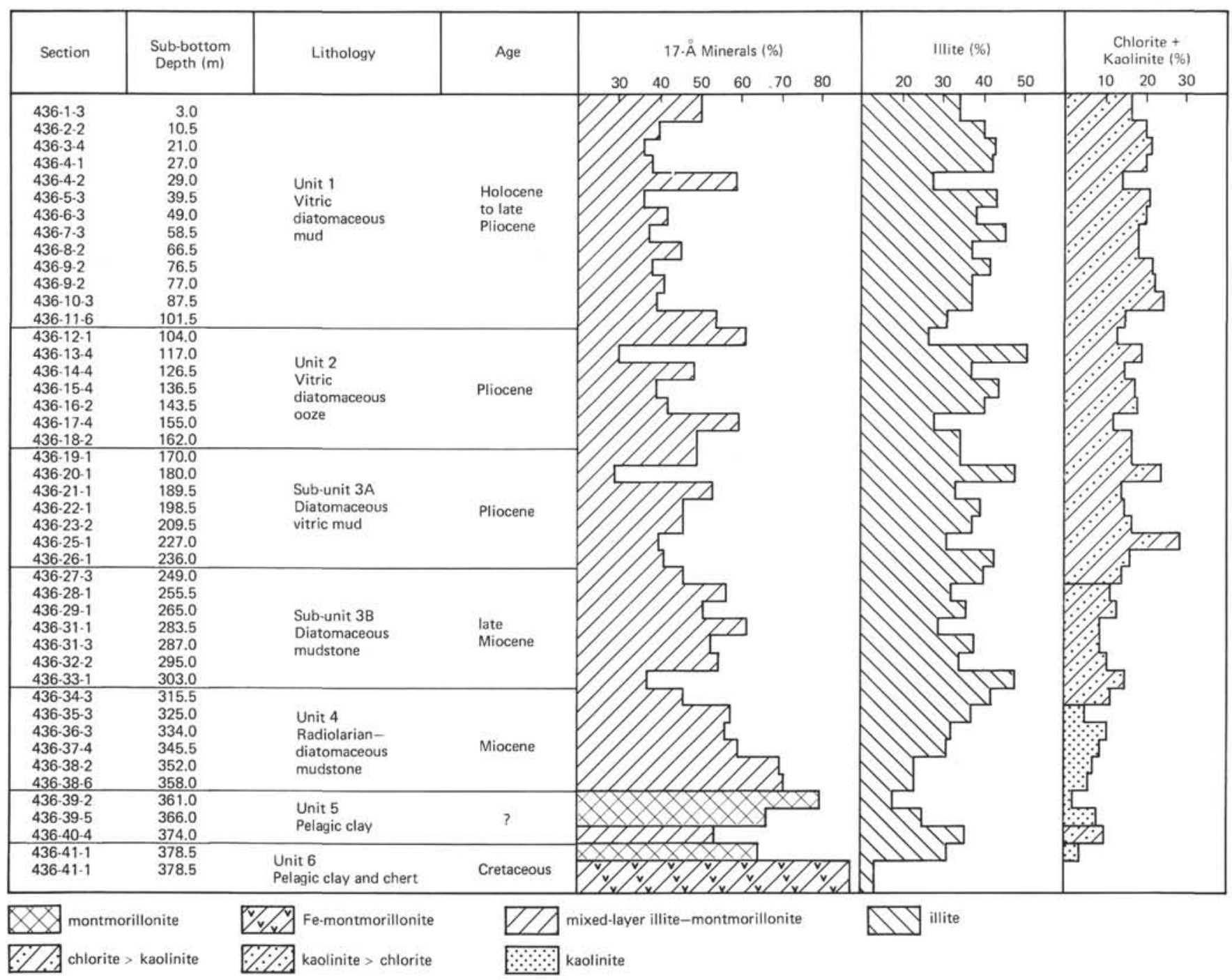

Figure 5. Variations in clay minerals composition of the less than $1 \mu \mathrm{m}$ fraction from Site 436.

3, Figure 3). We found traces of palygorskite-sepiolitic group minerals throughout Site 436. These minerals are probably authigenic.

\section{Correlation}

We correlated sediments from Leg 56, beginning with the upper Miocene sediments recovered at Sites 434 and 436. The upper Miocene diatomaceous mudstones at Site 436 occur in the passage bed, and despite common mineralogical features with the upper Miocene sediments from Site 434 they differ from the latter. Sediments at Site 436 compared with those from Site 434 contain more 17 - $\AA$ expanding minerals. In addition, the less than $1 \mu \mathrm{m}$ and 1 to $10 \mu \mathrm{m}$ fractions from sediments drilled at Site $436,7-\AA$ minerals are mostly chlorites and the number of $2 \mathrm{M}_{1}$ polytype illites increases. In the less than $1 \mu \mathrm{m}$ fraction we observed palygorskite-sepiolitic minerals only in sediments from Site 436 . In the upper Miocene sediments from Hole 434B mixed-layer chlorite-montmorillonite is absent. The upper Miocene sediments from Sites 434 and 436 also differ litholog- ically; tuffites occur at Site 434 and diatomaceous claystones occur at Site 436.

The Pliocene-Pleistocene terrigenous sediments in the less than $1 \mu \mathrm{m}$ and 1 to $10 \mu \mathrm{m}$ fractions at Sites 434 , 435 , and 436 have a similar composition of clay and coexisting minerals. Sediments from Site 435 contain more mixed-layer illite-montmorillonite and accordingly less illite and 7- $\AA$ minerals than sediments from Sites 434 and 436 . The $17-\AA$ mineral from the upper portion of the holes at Site 435 has a greater number of expanding layers. The mineralogical composition of fractions less than $1 \mu \mathrm{m}$ and 1 to $10 \mu \mathrm{m}$ at Sites 434 and 436 are similar. The main difference is a more widespread polytype $2 \mathrm{M}_{1}$ illite in Pliocene-Holocene sediments at Site 436; only in Hole 436 do admixtures of palygorskitesepiolitic minerals occur. Site 436 contains more 17 mineral than Site 434.

Thus comparison of mineralogical composition of the less than $1 \mu \mathrm{m}$ and $1-10 \mu \mathrm{m}$ fractions from different Leg 56 drilling sites shows that the Pliocene-Pleistocene sediments have much in common. 
TABLE 12

Sample Tests from DSDP Hole 436

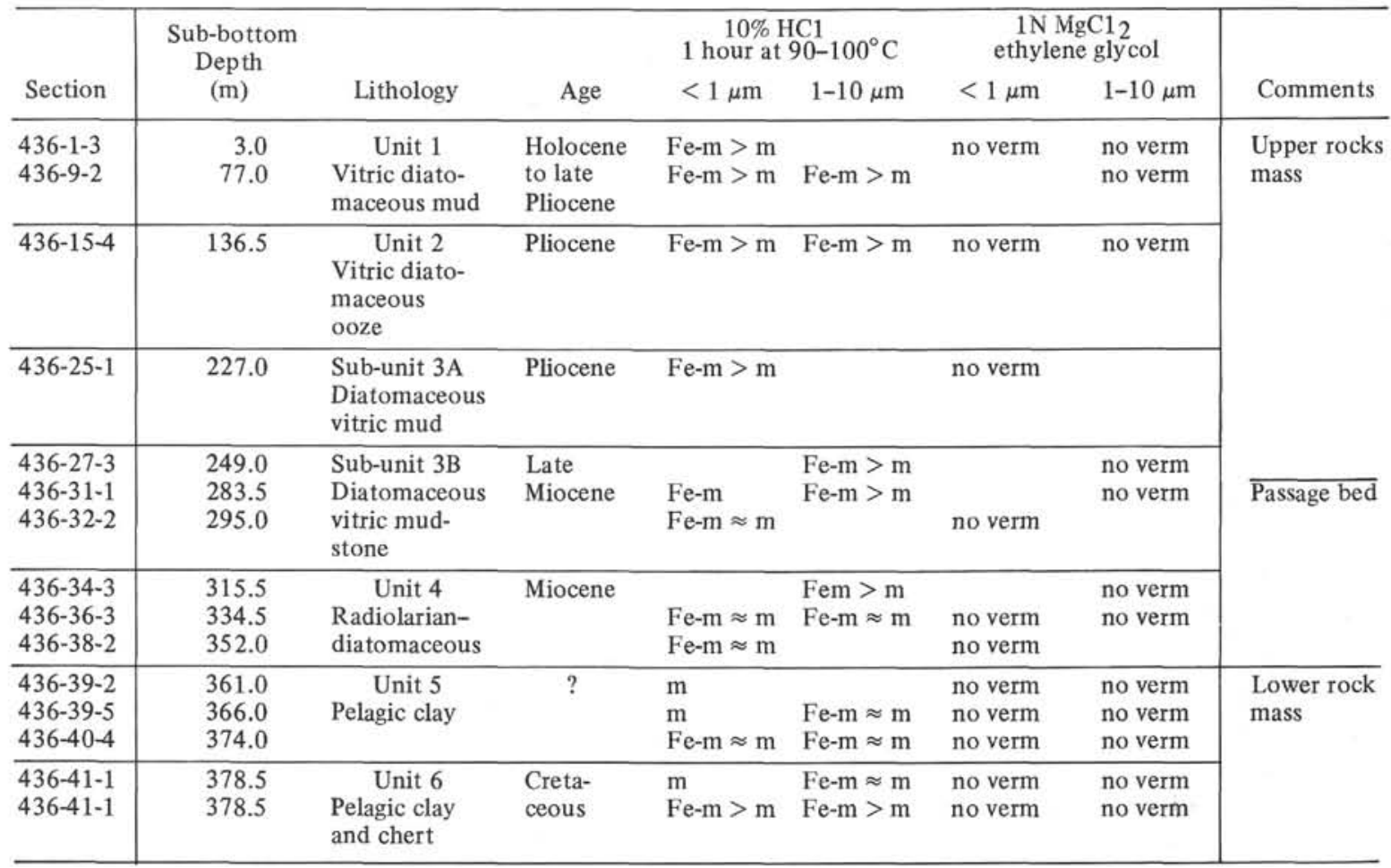

Note: $\mathrm{Fe}-\mathrm{m}=$ montmorillonite, $\mathrm{m}=$ montmorillonite, verm $=$ vermiculite.

TABLE 13

The $b$-Parameter in DSDP Hole 436

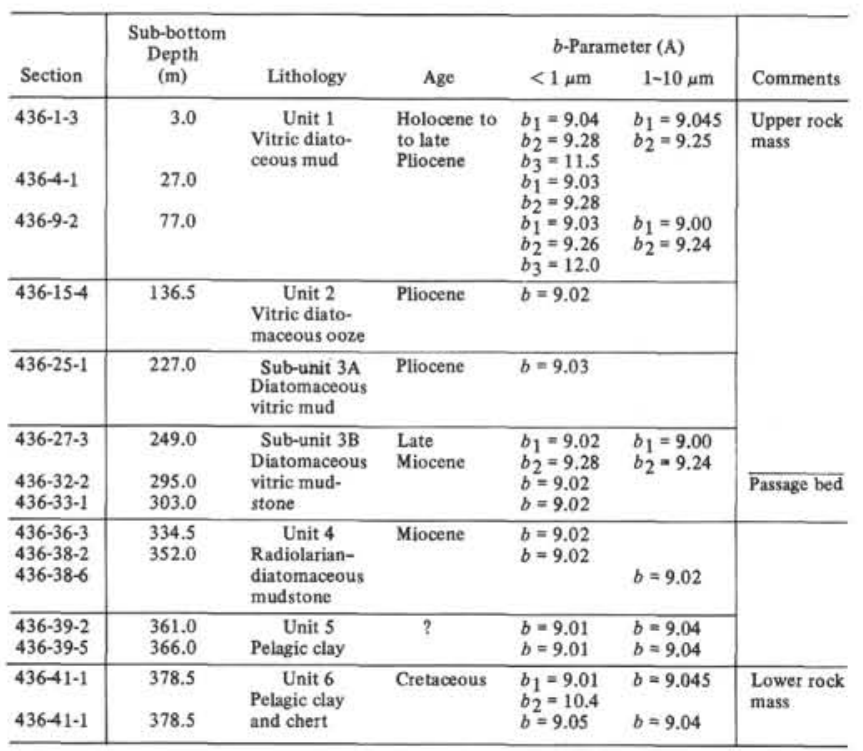

Stratigraphic analogs of more ancient sediments (pelagic clays and chert) are lacking at the other Leg 56 sites.

\section{Sedimentation History}

Both the mineralogy and grain size of pelagic clays clearly indicate deposition under conditions of very scarce terrigenous matter. Such conditions may have resulted from the presence of a barrier which separated
TABLE 14

Poly types of Illite in DSDP Hole 436

\begin{tabular}{|c|c|c|c|c|c|c|}
\hline \multirow[b]{2}{*}{ Section } & \multirow{2}{*}{$\begin{array}{l}\text { Sub-bottom } \\
\text { Depth } \\
\text { (m) }\end{array}$} & \multirow[b]{2}{*}{ Lithology } & \multirow[b]{2}{*}{ Age } & \multicolumn{2}{|c|}{ Poly type } & \multirow[b]{2}{*}{ Comments } \\
\hline & & & & $<1 \mu \mathrm{m}$ & $1-10 \mu \mathrm{m}$ & \\
\hline $\begin{array}{l}436-1-3 \\
436-4-1 \\
436-9-2\end{array}$ & $\begin{array}{r}3.0 \\
27.0 \\
77.0\end{array}$ & $\begin{array}{l}\text { Unit } 1 \\
\text { Vitric diato- } \\
\text { maceous mud }\end{array}$ & $\begin{array}{l}\text { Holocene to } \\
\text { late Pliocene }\end{array}$ & $\begin{array}{l}2 M_{1} \\
2 M_{1} \\
2 M_{1}>1 M\end{array}$ & $\begin{array}{l}? \\
?\end{array}$ & \multirow[t]{3}{*}{$\begin{array}{l}\text { Upper rock } \\
\text { mass }\end{array}$} \\
\hline $436-15-4$ & 136.5 & $\begin{array}{c}\text { Unit } 2 \\
\text { Vitric diato- } \\
\text { maceous ooze }\end{array}$ & Pliocene & $2 \mathrm{M}_{1}>1 \mathrm{M}$ & & \\
\hline $436-25-1$ & 227.0 & $\begin{array}{l}\text { Sub-unit 3A } \\
\text { Diatomaceous } \\
\text { vitric mud }\end{array}$ & Pliocene & $2 \mathrm{M}_{1}>1 \mathrm{M}$ & & \\
\hline $\begin{array}{l}436-27-3 \\
436-32-2 \\
436-33-1\end{array}$ & $\begin{array}{l}249.0 \\
295.0 \\
303.0\end{array}$ & $\begin{array}{l}\text { Sub-unit 3B } \\
\text { Diatomaceous } \\
\text { vitric mud- } \\
\text { stone }\end{array}$ & $\begin{array}{l}\text { Late } \\
\text { Miocene }\end{array}$ & $\begin{array}{l}2 M_{1}>1 M \\
2 M_{1}>1 M \\
2 M_{1}>1 M\end{array}$ & $2 \mathrm{M}_{1}>1 \mathrm{M}$ & \multirow[t]{2}{*}{$\overline{\text { Passage bed }}$} \\
\hline $\begin{array}{l}436-36-3 \\
436-38-2 \\
436-38-6\end{array}$ & $\begin{array}{l}334.5 \\
352.0 \\
358.0\end{array}$ & $\begin{array}{l}\quad \text { Unit } 4 \\
\text { Radiolarian- } \\
\text { diatomaceous } \\
\text { mudstone }\end{array}$ & Miocene & $\begin{array}{l}2 M_{1}>1 M \\
2 M_{1}>1 M\end{array}$ & $2 \mathrm{M}_{1}$ & \\
\hline $\begin{array}{l}436-39-2 \\
436-39-5\end{array}$ & $\begin{array}{l}361.0 \\
366.0\end{array}$ & $\begin{array}{c}\text { Unit } 5 \\
\text { Pelagic clay }\end{array}$ & $?$ & $\begin{array}{l}2 \mathrm{M}_{1}>1 \mathrm{M} \\
2 \mathrm{M}_{1}>1 \mathrm{M}\end{array}$ & $\begin{array}{l}2 \mathrm{M}_{1} \\
2 \mathrm{M}_{1}\end{array}$ & \multirow[t]{2}{*}{$\begin{array}{l}\text { Lower rock } \\
\text { mass }\end{array}$} \\
\hline $\begin{array}{l}436-41-1 \\
436-41-1\end{array}$ & $\begin{array}{l}378.5 \\
378.5\end{array}$ & $\begin{array}{l}\quad \text { Unit } 6 \\
\text { Pelagic clay } \\
\text { and chert }\end{array}$ & Cretaceous & $\begin{array}{l}2 \mathrm{M}_{1} \\
2 \mathrm{M}_{1}\end{array}$ & $\begin{array}{l}2 \mathrm{M}_{1}>1 \mathrm{M} \\
2 \mathrm{M}_{1}>1 \mathrm{M}\end{array}$ & \\
\hline
\end{tabular}

Note: $>=$ much greater than.

the land source from the area of sediment accumulation or from the fact that this area was located in a pelagic environment far from shore. The existence of a barrier between Japan and the Japan Trench in the late Oligocene-early Miocene (Oyashio landmass) has been suggested by Leg 57 participants, and our own mineralogical data support this hypothesis. We assume this barrier to have extended far southward, screening terrigenous suspension from both the Japanese Islands and Southeast Asia. 
TABLE 15

Grain-Size Determination from DSDP Hole 436

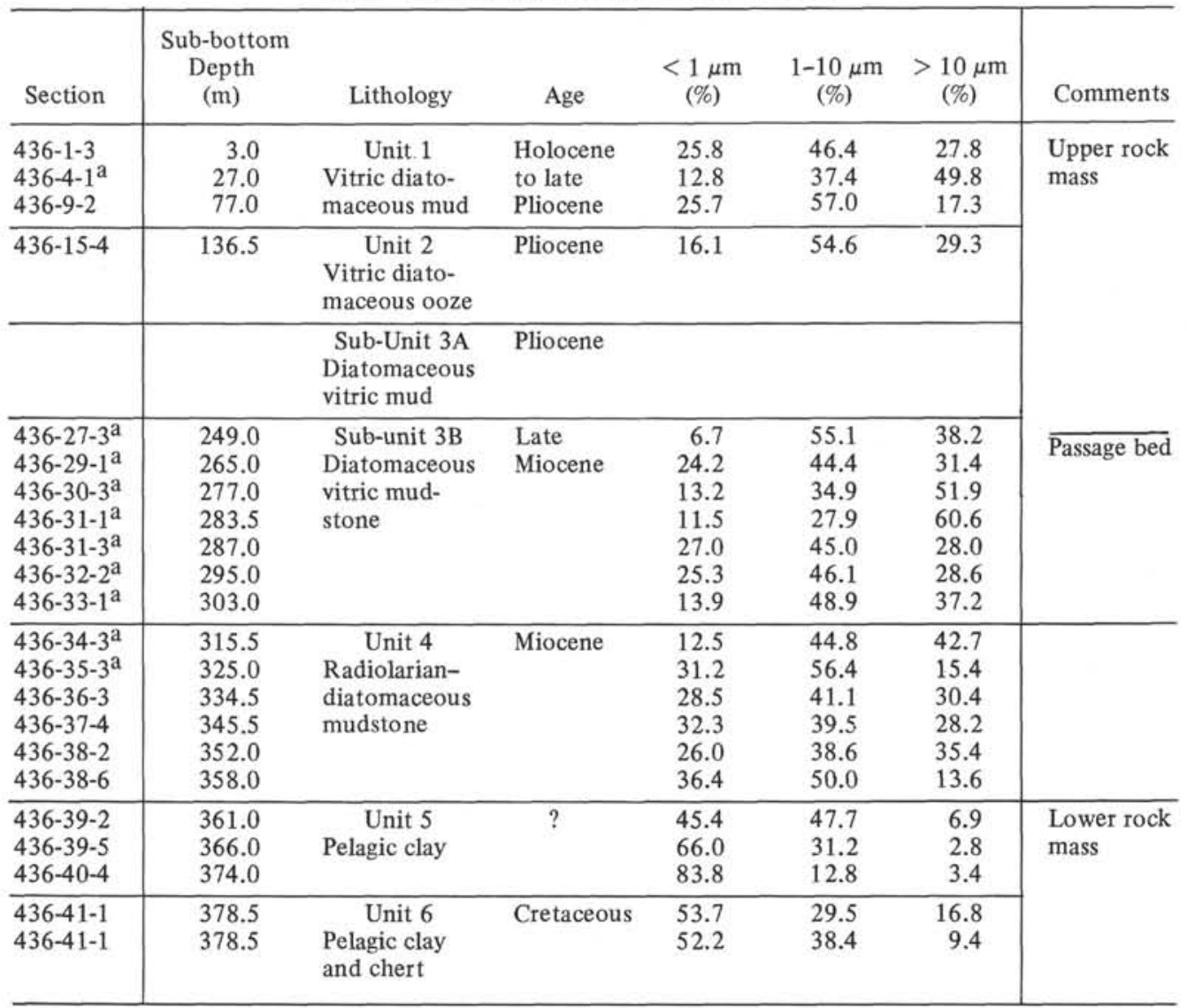

${ }^{\mathrm{a}}$ Flakeform suspension.

TABLE 16

Composition of the Fraction $<1 \mu \mathrm{m}$ from DSDP Leg 56 Holes

\begin{tabular}{|c|c|c|c|c|c|c|c|c|c|c|c|c|c|c|c|c|c|}
\hline $\begin{array}{c}\text { Sample } \\
\text { (Interval in } \mathrm{cm} \text { ) }\end{array}$ & $\begin{array}{l}\text { Sub-bottom } \\
\text { Depth } \\
\text { (m) }\end{array}$ & Lithology & Age & $\mathrm{SiO}_{2}$ & $\mathrm{TiO}_{2}$ & $\mathrm{Al}_{2} \mathrm{O}_{3}$ & $\mathrm{Fe}_{2} \mathrm{O}_{3}$ & $\mathrm{FeO}$ & $\mathrm{MnO}$ & $\mathrm{MgO}$ & $\mathrm{CaO}$ & $\mathrm{Na}_{2} \mathrm{O}$ & $\mathrm{K}_{2} \mathrm{O}$ & $\mathrm{H}_{2} \mathrm{O}^{-}$ & $\mathrm{H}_{2} \mathrm{O}^{+}$ & Total & Comments \\
\hline $434-1-2,30-35$ & 1.5 & Unit 1 & $\begin{array}{l}\text { Pliocene to } \\
\text { Pleistocene }\end{array}$ & 59.10 & 0.67 & 12.72 & 6.65 & 1.89 & 0.10 & 3.44 & 2.36 & 0.83 & 1.82 & 3.58 & 6.54 & 99.70 & \\
\hline $\begin{array}{l}434-12-1,85-89 \\
434-31-1,51-55 \\
\end{array}$ & $\begin{array}{l}102.0 \\
282.0 \\
\end{array}$ & Unit 2 & $\begin{array}{l}\text { Lower } \\
\text { Pliocene }\end{array}$ & $\begin{array}{l}66.40 \\
60.95\end{array}$ & $\begin{array}{l}0.54 \\
0.58\end{array}$ & $\begin{array}{l}10.34 \\
13.26\end{array}$ & $\begin{array}{l}3.77 \\
2.31\end{array}$ & $\begin{array}{l}1.54 \\
2.67\end{array}$ & $\begin{array}{l}0.09 \\
0.04\end{array}$ & $\begin{array}{l}3.60 \\
2.12\end{array}$ & $\begin{array}{l}1.13 \\
0.61\end{array}$ & $\begin{array}{l}0.57 \\
0.65\end{array}$ & $\begin{array}{l}1.56 \\
1.70\end{array}$ & $\begin{array}{l}3.46 \\
2.00\end{array}$ & $\begin{array}{r}6.68 \\
13.02 \\
\end{array}$ & $\begin{array}{l}99.68 \\
99.91 \\
\end{array}$ & \\
\hline $\begin{array}{l}434 \mathrm{~B}-2-1,2-19 \\
434 \mathrm{~B}-16-3,100-104\end{array}$ & $\begin{array}{l}295.5 \\
432.0 \\
\end{array}$ & Unit 3 & $\begin{array}{l}\text { Lower } \\
\text { Pliocene }\end{array}$ & $\begin{array}{l}56.50 \\
66.80 \\
\end{array}$ & $\begin{array}{l}0.56 \\
0.59\end{array}$ & $\begin{array}{l}15.50 \\
10.87 \\
\end{array}$ & $\begin{array}{l}.22 \\
4.68 \\
\end{array}$ & $\begin{array}{l}.06 \\
0.72 \\
\end{array}$ & $\begin{array}{l}0.06 \\
0.06 \\
\end{array}$ & $\begin{array}{l}2.49 \\
2.91 \\
\end{array}$ & $\begin{array}{l}0.54 \\
0.97 \\
\end{array}$ & $\begin{array}{l}0.54 \\
0.65 \\
\end{array}$ & $\begin{array}{l}2.93 \\
1.40 \\
\end{array}$ & $\begin{array}{l}5.72 \\
3.23 \\
\end{array}$ & $\begin{array}{l}8.41 \\
7.46 \\
\end{array}$ & $\begin{array}{r}99.53 \\
100.34 \\
\end{array}$ & \\
\hline $\begin{array}{l}434 \mathrm{~B}-28-1,70-74 \\
434 \mathrm{~B}-33-1,145\end{array}$ & $\begin{array}{l}543.0 \\
591.0 \\
\end{array}$ & Unit 4 & $\begin{array}{l}\text { Upper } \\
\text { Miocene }\end{array}$ & $\begin{array}{l}64.50 \\
56.40 \\
\end{array}$ & $\begin{array}{l}0.61 \\
0.58\end{array}$ & $\begin{array}{l}11.40 \\
16.44 \\
\end{array}$ & $\begin{array}{l}6.41 \\
3.44 \\
\end{array}$ & $\begin{array}{l}0.77 \\
2.06\end{array}$ & $\begin{array}{l}0.09 \\
0.06\end{array}$ & $\begin{array}{l}3.25 \\
2.68\end{array}$ & $\begin{array}{l}1.78 \\
0.61\end{array}$ & $\begin{array}{l}0.97 \\
0.57\end{array}$ & $\begin{array}{l}1.64 \\
3.19\end{array}$ & $\begin{array}{l}2.77 \\
3.81\end{array}$ & $\begin{array}{r}5.50 \\
10.05\end{array}$ & $\begin{array}{l}99.69 \\
99.89\end{array}$ & \\
\hline $434 \mathrm{~B}-37-1,26-30$ & 628.0 & Unit 5 & $\begin{array}{l}\text { Upper } \\
\text { Miocene }\end{array}$ & 63.40 & 0.65 & 12.26 & 5.28 & 1.13 & 0.07 & 2.56 & 1.13 & 0.66 & 1.49 & 2.81 & 8.83 & 100.27 & \\
\hline $435-1-1,54-58$ & 0.5 & Unit 1 & Pleistocene & 54.25 & 0.70 & 13.66 & 7.96 & 2.88 & 0.04 & 2.44 & 0.75 & 0.73 & 1.81 & 3.56 & 10.80 & 99.58 & \\
\hline $\begin{array}{l}435 \mathrm{~A}-7-1,80-84 \\
435 \mathrm{~A}-10-1,74-78\end{array}$ & $\begin{array}{l}197.5 \\
226.0\end{array}$ & & Pliocene & $\begin{array}{l}63.15 \\
63.35\end{array}$ & $\begin{array}{l}0.53 \\
0.50\end{array}$ & $\begin{array}{r}11.10 \\
7.36\end{array}$ & $\begin{array}{l}3.84 \\
3.66\end{array}$ & $\begin{array}{l}1.44 \\
1.44\end{array}$ & $\begin{array}{l}0.03 \\
0.05\end{array}$ & $\begin{array}{l}1.71 \\
1.76\end{array}$ & $\begin{array}{l}0.75 \\
1.56\end{array}$ & $\begin{array}{l}0.70 \\
0.70\end{array}$ & $\begin{array}{l}1.44 \\
1.74\end{array}$ & $\begin{array}{l}1.77 \\
1.85\end{array}$ & $\begin{array}{l}14.03 \\
13.60\end{array}$ & $\begin{array}{r}100.49 \\
99.57\end{array}$ & \\
\hline $\begin{array}{l}436-1-3,20-25 \\
436-9-2,120-125\end{array}$ & $\begin{array}{r}3.0 \\
77.0\end{array}$ & Unit 1 & $\begin{array}{l}\text { Holocene } \\
\text { to late } \\
\text { Pliocene }\end{array}$ & $\begin{array}{l}52.80 \\
59.00\end{array}$ & $\begin{array}{l}0.72 \\
0.56\end{array}$ & $\begin{array}{l}15.91 \\
14.06\end{array}$ & $\begin{array}{l}6.36 \\
4.06\end{array}$ & $\begin{array}{l}1.74 \\
1.85\end{array}$ & $\begin{array}{l}0.01 \\
0.03\end{array}$ & $\begin{array}{l}2.64 \\
2.59\end{array}$ & $\begin{array}{l}0.48 \\
0.68\end{array}$ & $\begin{array}{l}0.78 \\
0.73\end{array}$ & $\begin{array}{l}2.07 \\
1.81\end{array}$ & $\begin{array}{l}2.44 \\
2.20\end{array}$ & $\begin{array}{l}13.83 \\
12.30\end{array}$ & $\begin{array}{l}99.78 \\
99.87\end{array}$ & $\begin{array}{l}\text { Upper rock } \\
\text { mass }\end{array}$ \\
\hline $436-15-4,60-64$ & 136.5 & Unit 2 & Pliocene & 56.60 & 0.64 & 14.59 & 4.21 & 2.05 & 0.01 & 2.49 & 0.68 & 0.73 & 2.34 & 2.56 & 12.60 & 99.50 & \\
\hline $\begin{array}{l}436-31-3,65-69 \\
436-33-1,56-60 \\
\end{array}$ & $\begin{array}{l}287.0 \\
303.0 \\
\end{array}$ & $\begin{array}{c}\text { Sub-unit } \\
\text { 3B }\end{array}$ & $\begin{array}{l}\text { Late } \\
\text { Miocene }\end{array}$ & $\begin{array}{l}57.30 \\
56.90 \\
\end{array}$ & $\begin{array}{l}0.61 \\
0.58 \\
\end{array}$ & $\begin{array}{l}16.22 \\
15.65 \\
\end{array}$ & $\begin{array}{l}5.29 \\
5.47 \\
\end{array}$ & $\begin{array}{l}1.44 \\
1.44\end{array}$ & $\begin{array}{l}0.02 \\
0.08\end{array}$ & $\begin{array}{l}2.10 \\
1.95 \\
\end{array}$ & $\begin{array}{l}0.61 \\
0.88\end{array}$ & $\begin{array}{l}0.78 \\
0.78 \\
\end{array}$ & $\begin{array}{l}2.13 \\
2.13 \\
\end{array}$ & $\begin{array}{l}0.89 \\
3.06 \\
\end{array}$ & $\begin{array}{l}12.11 \\
11.27 \\
\end{array}$ & $\begin{array}{r}99.50 \\
100.19 \\
\end{array}$ & Passage bed \\
\hline $436-38-6,90-94$ & 358.0 & Unit 4 & Miocene & 52.40 & 0.58 & 17.24 & 5.43 & 1.23 & 0.69 & 2.68 & 0.54 & 0.54 & 2.07 & 6.93 & 9.23 & 99.56 & \\
\hline $436-39-2,26-30$ & 361.0 & Unit 5 & $?$ & 51.05 & 0.64 & 15.38 & 5.16 & 1.03 & 0.78 & 3.81 & 0.68 & 0.46 & 1.44 & 10.00 & 9.17 & 99.60 & Lower \\
\hline $\begin{array}{l}436-41-1,10-12 \\
436-41-1,34-36\end{array}$ & $\begin{array}{l}378.5 \\
378.5\end{array}$ & Unit 6 & Cretaceous & $\begin{array}{l}47.40 \\
49.45\end{array}$ & $\begin{array}{l}0.93 \\
0.58\end{array}$ & $\begin{array}{l}16.71 \\
13.33\end{array}$ & $\begin{array}{r}7.68 \\
10.14\end{array}$ & $\begin{array}{l}1.05 \\
0.82\end{array}$ & $\begin{array}{l}0.81 \\
0.08\end{array}$ & $\begin{array}{l}3.88 \\
3.37\end{array}$ & $\begin{array}{l}0.88 \\
1.02\end{array}$ & $\begin{array}{l}0.46 \\
0.41\end{array}$ & $\begin{array}{l}2.13 \\
1.92\end{array}$ & $\begin{array}{l}7.67 \\
9.32\end{array}$ & $\begin{array}{r}10.05 \\
9.54\end{array}$ & $\begin{array}{l}99.65 \\
99.98\end{array}$ & \\
\hline
\end{tabular}


Data on clay and coexisting minerals as well as grain size analysis of sediments from Site 436 indicate that the transport of terrigenous material began in small quantities in the Miocene and became abundant at the end of the late Miocene, resulting in a transition from a pelagic to a hemipelagic environment. This coincides with the subsidence of the Oyashio Landmass in the early Miocene. We suggest it completely disappeared as a barrier for terrigenous sediments in the late Miocene. This conclusion is in agreement with the theories of Nasu et al. (this volume), who suggested the existence of the Oyashio Landmass between Japan and the Japan Trench. The active delivery of terrigenous sediments beginning in the early Miocene-early Pliocene is typical of the entire western Pacific (Gorbunova, 1975).

In the late Miocene only terrigenous clay minerals accumulated in the Japan Trench (Site 434), whereas on the oceanic plate (Site 436) there are traces of authigenic minerals (e.g., clinoptilolite and palygorskite) as well.

Thus we may interpret the clay minerals in pre-Pliocene sediments (Site 434 in the Japan Trench and Site 436 at the margin of the oceanic plate) without the hypothesis of a westward movement of the oceanic plate from the central Pacific to the Japan Trench. However, mineralogical data do not preclude the possibility of oceanic plate movement. If we compare upper Miocene sediments, the identical mineralogical composition of sediments from the Japan Trench and the oceanic plate cannot be used to differentiate these sediments in the accretionary wedge.

The Pliocene-Pleistocene sediments drilled at Sites 434,435 , and 436 formed in a terrigenous sedimentation environment identical or similar to the Recent. Recent terrigenous matter in the Japan Trench sediments is derived in part from the Japan islands and in part from Southeast Asia (carried by the Kuroshio Current). The Japanese islands deliver mainly 17 - $\AA$ minerals, and the Kuroshio Current contains abundant illites of the $2 \mathrm{M}_{1}$ polytype (Rateev et al., 1966; Griffin et al., 1968; Gorbunova, 1970; Lisitsyna et al., 1973; Kurnosov and Murdmaa, 1976).

We have found the same regularities in the composition and distribution of clay minerals in the PliocenePleistocene sediments from Leg 56 drilling sites which characterize the surface layer of Recent sediments in the area. These are a decrease of $17-\AA$ mineral content offshore, and an increase in illite and polytype $2 \mathrm{M}_{1}$ content. Thus beginning in the late Miocene-early Pliocene, the sedimentation environment resembles the Recent one. The main sources were Southeast Asia and Japan.

Quantitative variations in clay mineral content in sediments recovered from the Japan Trench, its slope, and from the oceanic plate reflect the variations in mineral composition of terrigenous suspended matter deposited in these areas during the Pliocene-Pleistocene. Changes of sediment source and unstable water circulation transporting suspended material in the western $\mathrm{Pa}$ cific may have caused these variations. Because water circulation is the most variable factor in deposition, despite possible changes in source areas in the PliocenePleistocene, we suggest periodic current fluctuations to be the main reason for variations of clay mineral content. A similar variability due to the change of hydrodynamic environment has been reported in the Sea of Japan (Kurnosov, 1977). Variations of clay mineral content in Pliocene-Pleistocene deposits show the paleocurrent migration of the Kuroshio Current. When it approached the Japanese islands, sediments were enriched in illite and depleted in $17-\AA$ mineral owing to suspension derived from Southeast Asia; when it moved offshore, the local sources (Japanese islands) greatly influenced sedimentation - that is, $17-\AA$ mineral increased and illite decreased.

Thus beginning in the late Miocene-early Pliocene, sedimentation environment at Leg 56 sites has been similar to the Recent. Although we do not deny the possible influence of plate movements on Cretaceous-Pliocene sediments, sedimentation processes may be interpreted without the plate tectonics hypothesis.

\section{Diagenesis}

The role of clay minerals in the diagenesis of sediments is minor throughout. To the bottom of every hole $17-\AA$ mineral is somewhat enriched in potassium. We observed only the beginning of 17 - $\AA$ mineral micatization process. Distribution of microelements in clay fractions of terrigenous sediments is rather even. The possible role of clay minerals in sediment lithification without change in structure remains a subject for future study.

\section{CONCLUSIONS}

The clay minerals in Cretaceous and Pleistocene sediments recovered during Leg 56 may have been deposited when the oceanic plate was in its present position, without movement of the area of sedimentation relative to Asia plate. At the same time we accept the possibility that the oceanic plate descended into the Japan Trench. Beginning in the late Miocene-early Pliocene, the environment of sediment accumulation has been identical to the Recent. Only the migration of the Kuroshio paleocurrent disturbed this stability. The main terrigenous source areas were Japan and Southeast Asia. From the Cretaceous to the Miocene the sediment accumulation environment was influenced by the existence and subsequent destruction of the Oyashio Landmass, which screened terrigenous material transported from Japan and Southeast Asia.

Terrigenous clay minerals were virtually unaltered by diagenesis. Diagenesis produced only an increase in potassium in mixed-layer illite-montmorillonite.

Authigenic clay minerals in pelagic clays probably formed from dispersed volcanic glasses under the action of weak hydrothermal solutions or increased heat flow. They contain microelements characteristic of hydrothermal processes.

\section{ACKNOWLEDGMENTS}

We thank I. O. Murdmaa, A. Shevchenko, L. Kovbas, L. Avdevnina, and others at the Far East Geological Institute for their help in analyses and improvement of the manuscript. 


\section{REFERENCES}

Biscaye, P. E., 1964. Mineralogy and sedimentation of the deep-sea sediment fine fraction in the Atlantic Ocean. Geochem. Techn. Rept., 8, 803.

Bonatti, E., and Joensuu, O., 1968. Palygorskite from the deep sea. Amer. Mineral., 53, 975.

Butuzova, G. Yu., Lisitsyna, N. A., and Gradusov, B. P., 1977. Clay minerals in sediments along the profile across Pacific. Lithology and Minerals, 4, 3.

Chester, R., and Elderfield, H., 1973. An infrared study of clay minerals. 2 . The identification of kaolinite-group clays in deep-sea sediments. Chem. Geol., 12 (No. 4), 281.

Dritz, V. A., and Sakharov, B. A., 1976. X-ray Structure Analysis of Mixed-Layer Minerals: Moscow (Science Publishing House).

Gorbunova, Z. N., 1970. Clay and other highly dispersed minerals in Pacific sediments. The Pacific Ocean (Vol. 1): Moscow (Science Publishing House). 1975. The history of clay mineral accumulation in the Pacific in Cenozoic Time on the basis of deep-sea drilling. Oceanology, 15 (No. 5), 850.

Griffin, J. J., Windom, H., and Goldberg, E. D., 1968. The distribution of clay minerals in the World Ocean. Deep-Sea Research, 15, 433.

Kotov, N. B., Kurnosov, V. B., Kholodkevich, I. B., and Tseitlin, N. Yu., 1977. Experiments on hydrothermal transformations of glassy volcanic rock of plagiandesitic composition at increased $P-T$ parameters. Proceeds of Leningrad University, No. 24, Geol. Geog., 4, 33.

Kurnosov, V. B., 1977. The possibilities of the use of clay mineral distribution in oceanic sediments for the reconstruction of paleogeographic events during the Quaternary period. INQUA Congress Abstracts, 10, 261.
Kurnosov, V. B., and Murdmaa, I. O., 1976. Clay minerals in recent sediments of marginal seas of the Western Pacific. Lith. Min., 5, 22.

Kurnosov, V. B., Skornyakova, N. C., Murdmaa, I. O., Shevchenko, A. Ya., and Narnov, G. A., 1976. Morphologically unusual montmorillonites in products of underwater weathering of palagonitized glass. Repts. Acad. Sci. USSR, 231 (No. 4), 985.

Lisitsen, A. P., Serova, V. V., Zverinskaya, I. B., Lukashin, V., Gorbunova, Z. N., Gordeev, V. V., Zhurensko, V. V., Pchelintsev, A. M., Belyaev, Ju. I., Popov, N. I., Shishkina, O. V., Morozov, N. M., Jousé, A. P., Kozlova, O. G., Mukhina, V. V., Khodkevich, Yu. N., and Plyusnina, I. I., 1971. Geochemical, mineralogical, and paleontological studies. In Fischer, A. G., Heezen, B. C., et al., Init. Repts. DSDP, 6: Washington (U.S. Govt. Printing Office), 829-960.

Lisitsyna, N. A., Gradusov, B. P., Dvorstskaya, O. A., and Chizhikova, N. P., 1973. Clay minerals in sediments from the northwest Pacific. Lith. Min., 5, 5.

Okada, H., and Tomita, K., 1973. Clay mineralogy of deepsea sediments in the northwestern Pacific, DSDP, Leg 20. In Heezen, B. C., MacGregor, I. D., et al., Init. Repts. DSDP, 20: Washington (U.S. Govt. Printing Office), 335.

Rateev, M. A., Gorbunova, Z. N.,Lisitsyn, A. P., and Nosov, G. I., 1966. Climatic zonality of clay mineral distribution in Pacific sediments. Lith. Min., 3, 3.

Vikulova, M. F., 1957. Technique of Petrographical-Mineralogical Study of Clays. Moscow: Gosgeoltechizdat.

Weaver, C. E., 1968. The effects of geologic significance of potassium "fixation"' by expandable clay minerals derived from muscovite, biotite, chlorite, and volcanic materials. Am. Mineralogist, 43 (No. 9-10), 839.

\section{PLATE 1 \\ Electron Microscope Photos \\ $(<1 \mu \mathrm{m}$ fraction; magnification $\times 26,000$; \\ scale bar represents $0.2 \mu \mathrm{m}$ )}

Figure 1 Fragments of porous volcanic glass. Sample 434-1-2, $30-35 \mathrm{~cm}$.

Figures 2, 3 Clay minerals and porous volcanic glass.

2. Sample 434B-8-2, 33-37 cm.

3. Sample 434-23-1, 40-44 cm.

Figure 4 Kaolinite (?). Sample 436-38-2, 90-94 cm. 
PLATE 1
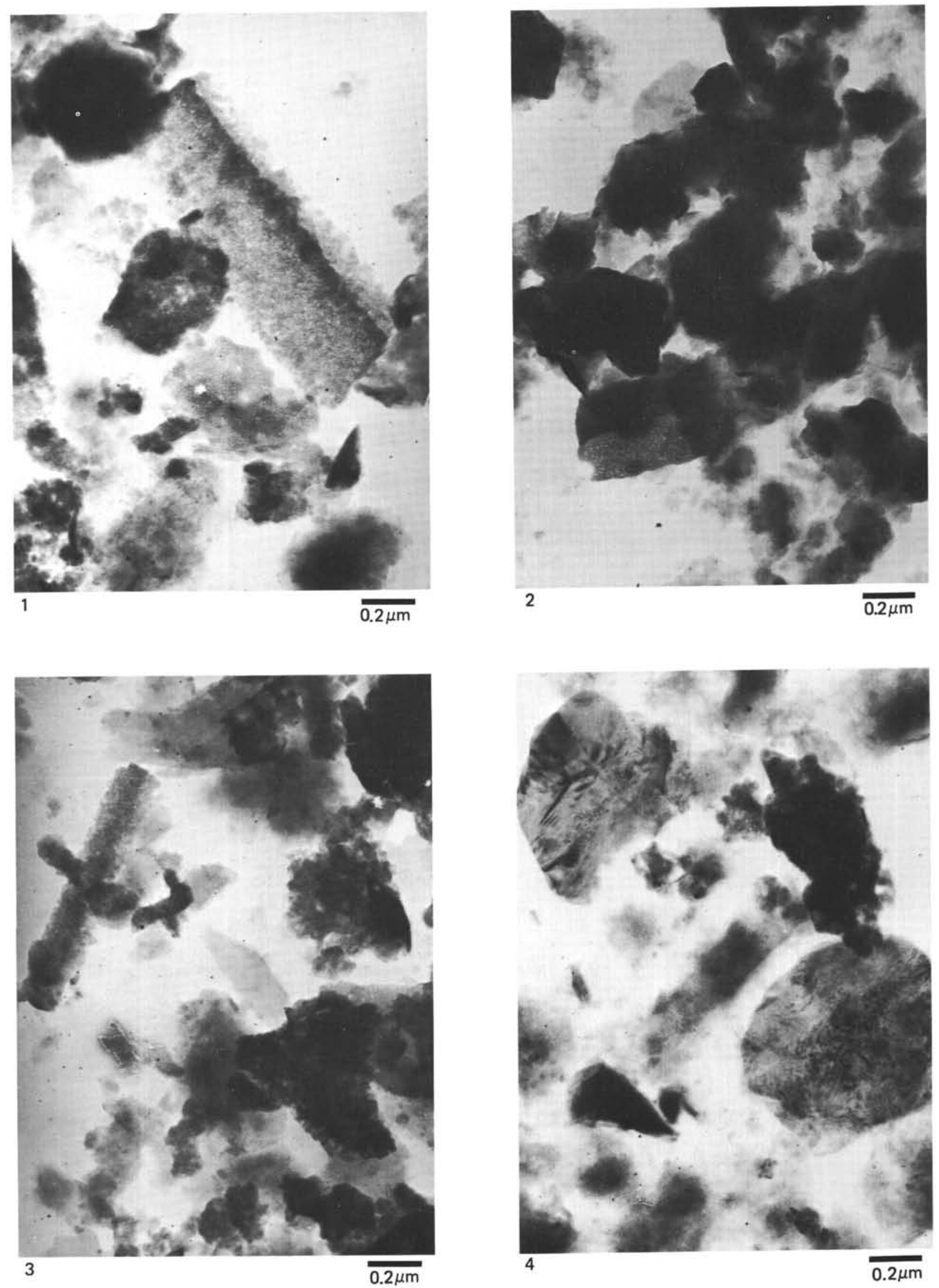
PLATE 2

Electron Microscope Photos

$(<1 \mu \mathrm{m}$ fraction; magnification $\times 26,000$; scale bar represents $0.2 \mu \mathrm{m}$ )

Figure 1 Montmorillonite. Sample 436-39-2, 26-30 cm.

Figure 2 Palygorskite and montmorillonite. Sample 436$39-5,76-80 \mathrm{~cm}$.

Figure 3 Palygorskite and montmorillonite. Sample 436$41-1,10-12 \mathrm{~cm}$.

Figure $4 \quad \mathrm{Fe}$-montmorillonite and palygorskite. Sample 436$41-1,34-36 \mathrm{~cm}$. 
PLATE 2
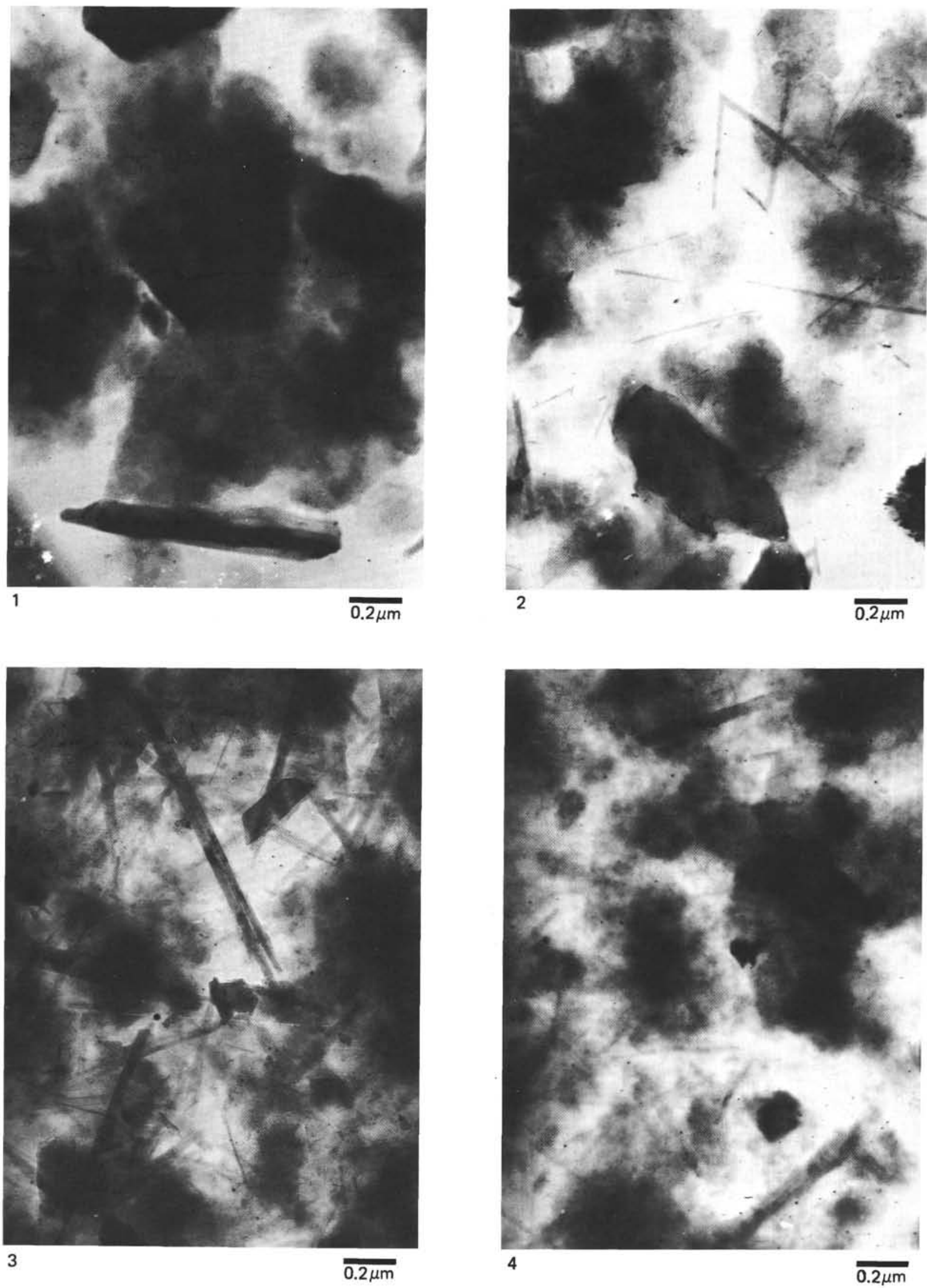
PLATE 3

Scanning Electron Microscope Photos

(Figures 1-3, magnification $\times 3000$; Figures $4-6$, magnification $\times 6000$; scale bar represents $2 \mu \mathrm{m}$ )

Figure 1 Terrigenous sediment. Sample 436-1-3, 20-25 cm.

Figure 2 Terrigenous sediment from passage bed, Site 436 . Sample 436-36-3, 50-54 cm.

Figure 3 Authigenic sediment with zeolites from passage bed, Site 436. Sample 436-36-3, 50-54 cm.

Figure 4 Authigenic 17- $\AA$ mineral. Sample 436-38-2, 90-94 $\mathrm{cm}$.

Figure $5 \quad$ Zeolites. Sample 436-39-2, 26-30 cm.

Figure 6 Zeolites. Sample 436-39-2, 26-30 cm. 


\section{PLATE 3}
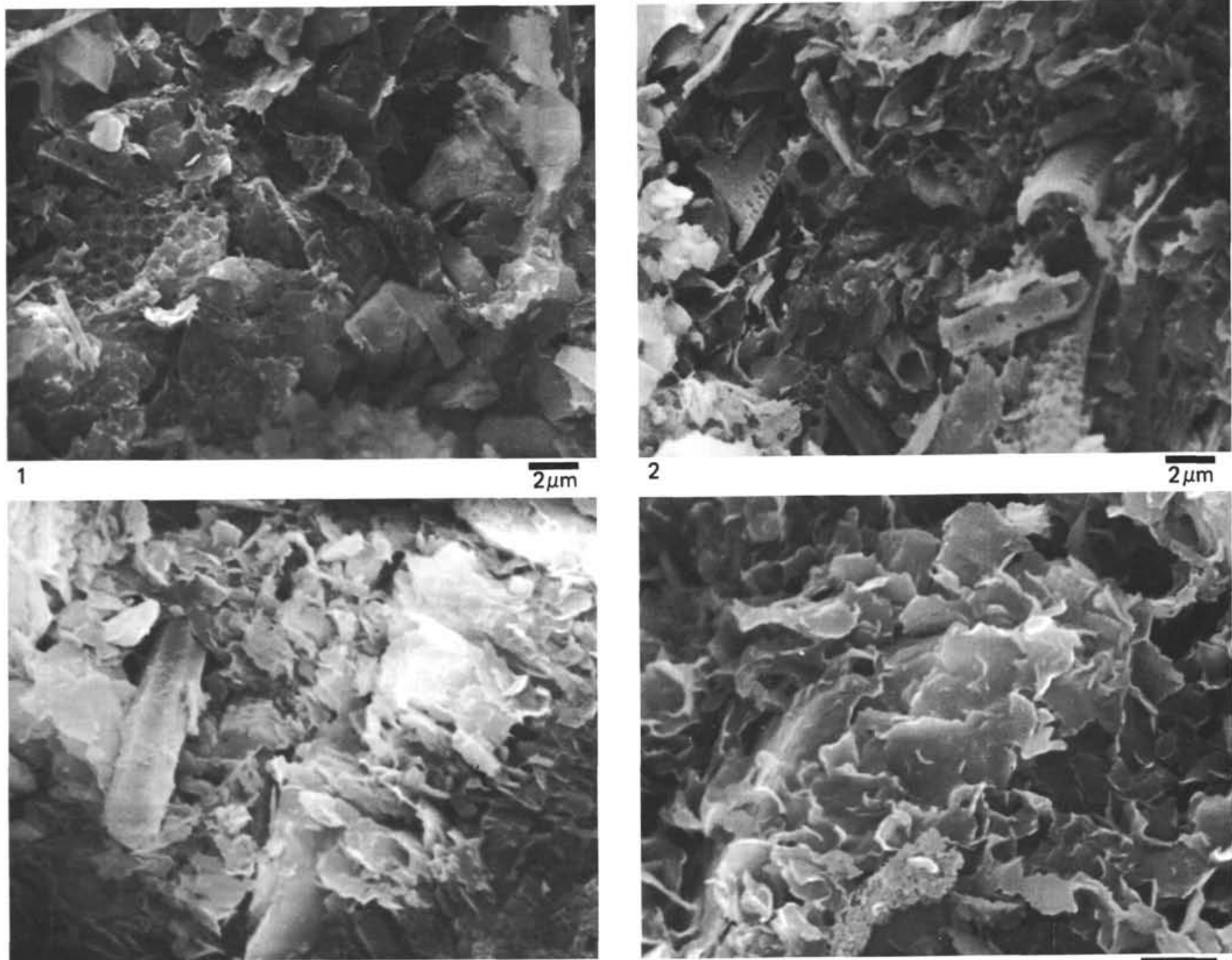

3

$\overline{2 \mu \mathrm{m}}$
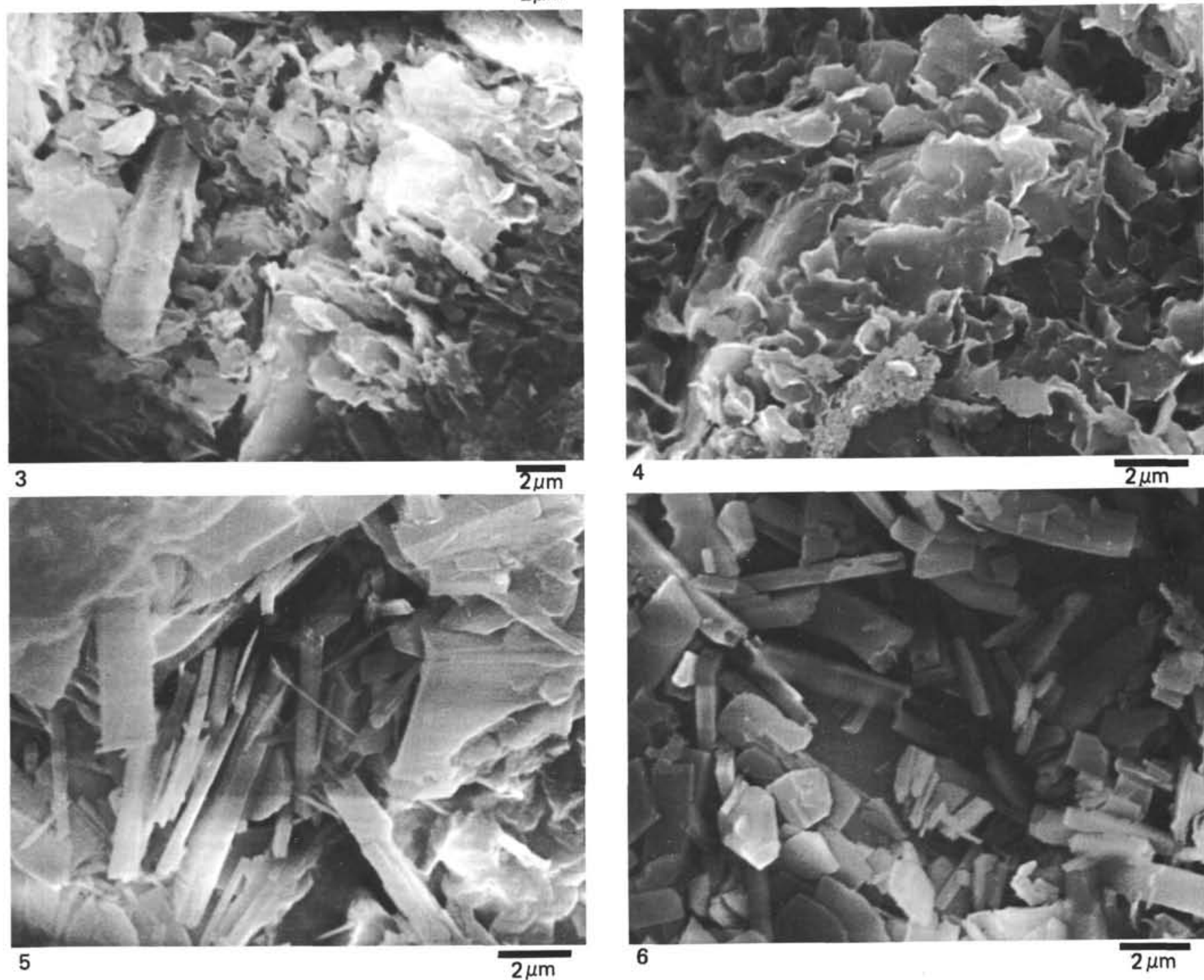

4

$2 \mu \mathrm{m}$

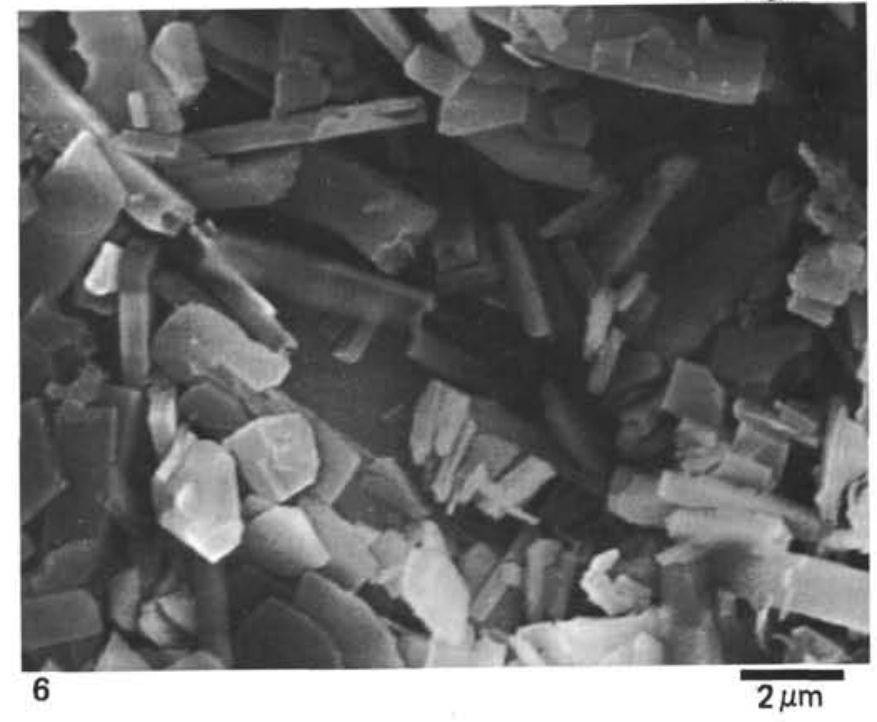


PLATE 4

Scanning Electron Microscope Photos

(Figures 1, 3-6, scale bar represents $2 \mu \mathrm{m}$;

Figure 2, scale bar represents $0.5 \mu \mathrm{m}$ )

Figure 1 Fragments of volcanic glass with spongy surface surrounded by authigenic montmorillonite. Sample 436-39-5, 76-80 cm. Magnification $\times 6000$.

Figure 2 Same volcanic glass as Figure 1. Sample 436-39-5, $76-80 \mathrm{~cm}$. Magnification $\times 20,000$.

Figure 3 Clinoptilolite. Sample 436-39-5, 76-80 cm. Magnification $\times 3000$.

Figure 4 Structure of authigenic Fe-montmorillonite. Sample 436-41-1, 34-36 cm. Magnification $\times 6000$.

Figures 5, 6 Sticks of palygorskite on authigenic montmorillonite. Sample 436-41-1, 10-12 cm.

5. Magnification $\times 3000$.

6. Magnification $\times 6000$. 
PLATE 4
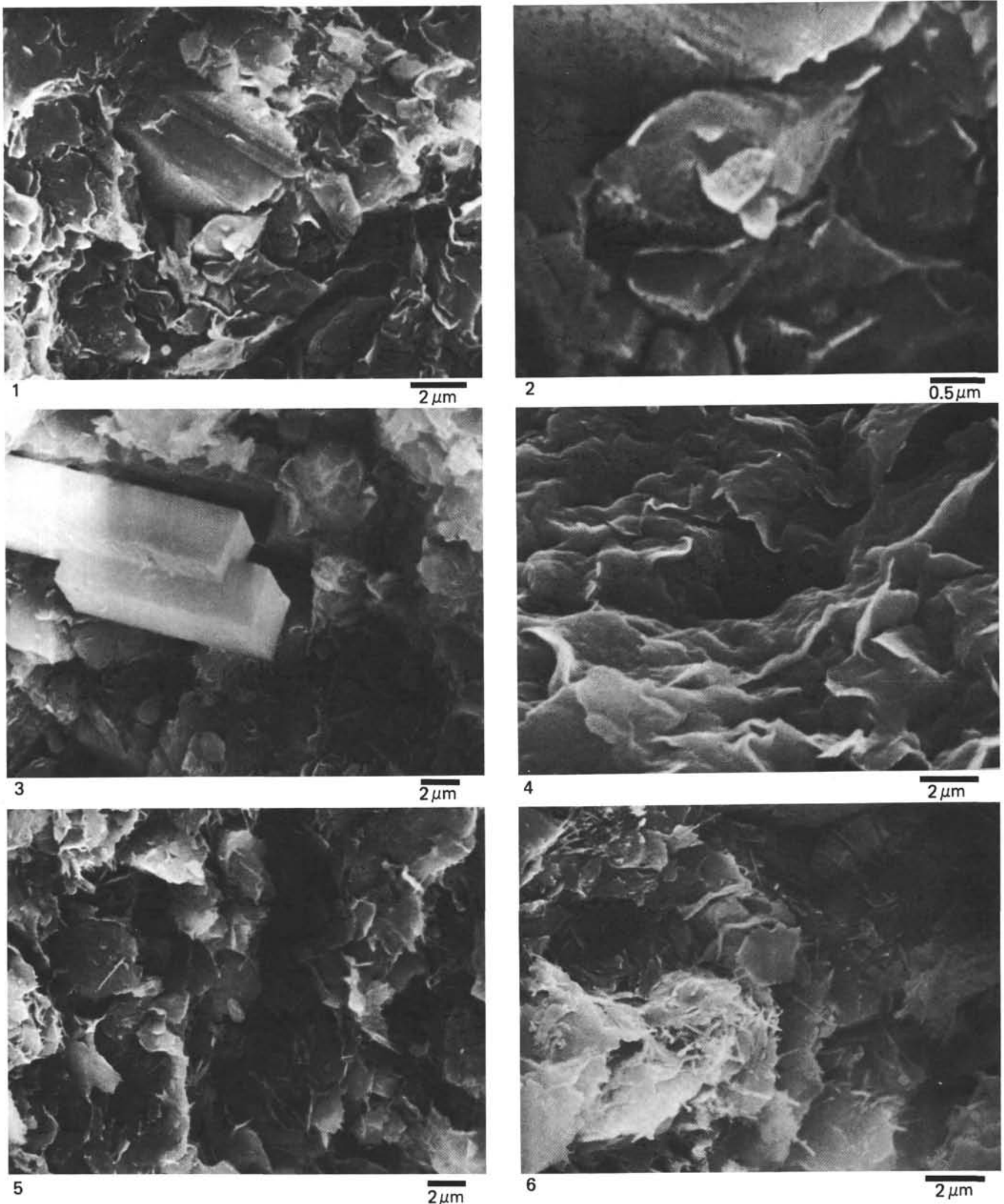
PLATE 5

Oblique Texture Electron Diffraction

( $<1 \mu$ m fraction)

Figure 1 Montmorillonite. Sample 436-39-2, 26-30 cm.

Figure 2 Fe-montmorillonite. Sample 436-41-1, 34-36 cm.

Figure 3 Typical mixed clay minerals from Leg 56 sites. Sample 436-4-1, 30-32 cm. 
PLATE 5
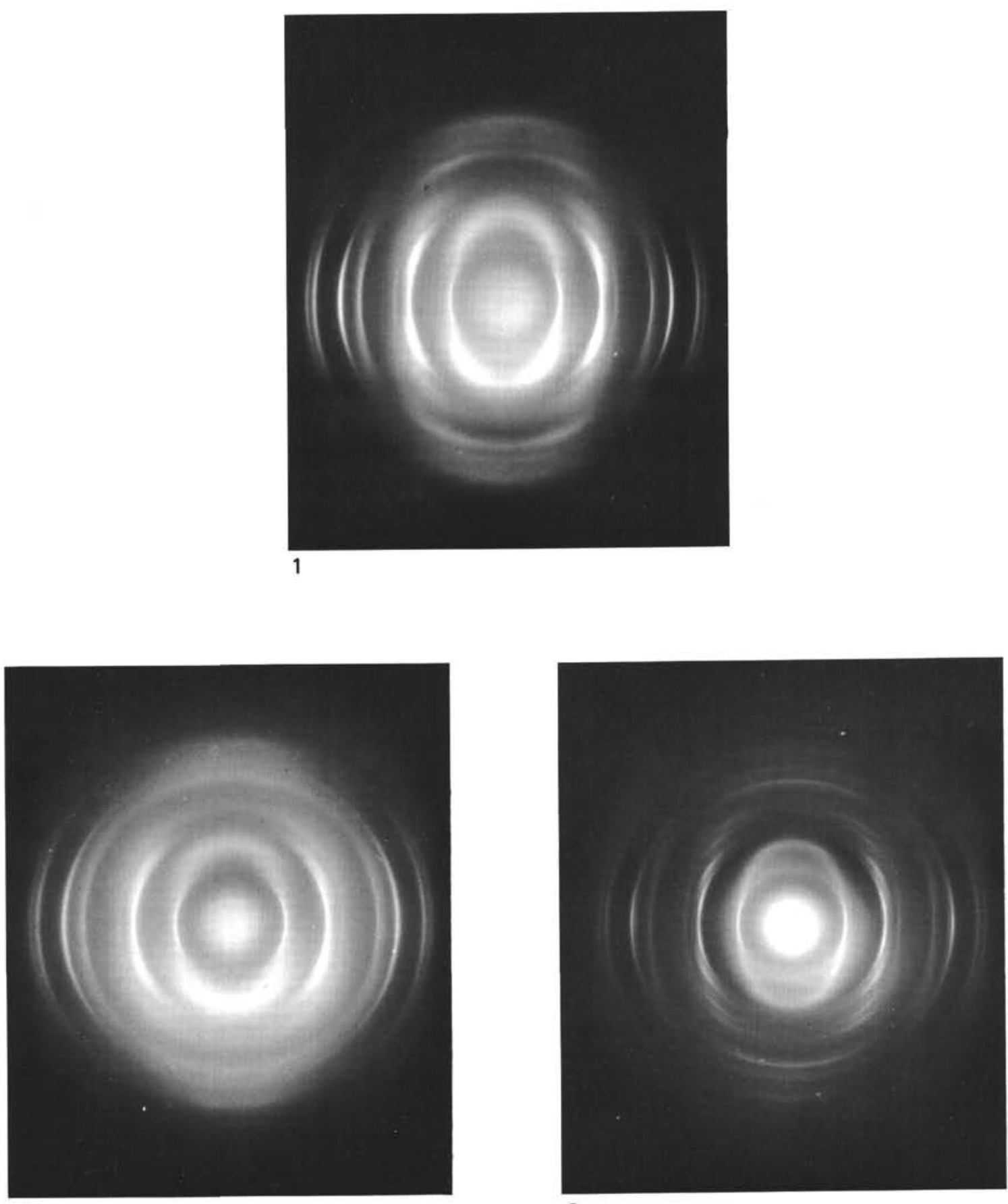

2

3 